\title{
Cardiovascular Autonomic Dysfunction in Diabetes as a Complication: Cellular and Molecular Mechanisms
}

\author{
Yu-Long Li \\ Department of Emergency Medicine, University of Nebraska Medical Center \\ United States of America
}

\section{Introduction}

Diabetes is a major world health problem, which affects more than 23 million people in the US and an estimated 250 million worldwide. Diabetes mellitus is a metabolic disease characterized by high blood glucose levels resulted from an inability in pancreatic insulin secretion or insulin resistance. Usually diabetes mellitus is mainly divided into type 1 diabetes characterized by loss of the insulin production from beta cells of the pancreatic islets and type 2 diabetes characterized by insulin resistance (defective responsiveness of body tissues to insulin) and relatively reduced insulin secretion. Although type II diabetes is by far the most common affecting 90 to $95 \%$ of the US diabetic population, the studies focusing on the type 1 diabetes cannot be ignored because about 1 in every 400 to 600 children and adolescents has type 1 diabetes and about 2 million adolescents aged 12-19 have pre-diabetes in the US.

Diabetes mellitus is chronic progressive disease that usually cannot be cured. Following the natural progression of disease, diabetes without proper treatments can cause many severe complications including diabetic ketoacidosis, cardiovascular disease, chronic renal failure, retinal damage. These complications obviously enhance the risk for diabetic patients. In these complications of the diabetes mellitus, cardiovascular autonomic dysfunction is a serious although poorly understood long term diabetic complication. Indeed, diabetic patients with cardiovascular autonomic dysfunction have consistently been shown to have an enhanced risk of premature death (Rosengard-Barlund et al., 2009). More importantly, the age-adjusted relative risk for cardiovascular disease in type 1 diabetes far exceeds that of type 2 diabetes (Krolewski et al., 1987; Libby et al., 2005). Therefore, exploring the mechanisms responsible to the cardiovascular autonomic dysfunction can provide an important and new pharmacological and genetic target for improving the prognosis and reducing the mortality in diabetic state.

\section{Baroreflex dysfunction in type 1 diabetes and the contribution of the baroreflex dysfunction in prognosis and mortality of the type 1 diabetes}

Cardiovascular autonomic function is the autonomic neural regulation of cardiovascular function, which presents the balance between sympathetic and parasympathetic innervation 
resulting in periodic fluctuation in heart rate and rhythm. Although there are many invasive and non-invasive methods to evaluate the cardiovascular autonomic function in diverse clinical and research settings, cardiovascular autonomic function typically is measured by a short-term evoked cardiovascular reflex, especially arterial baroreflex.

\subsection{Baroreflex dysfunction}

The arterial baroreflex normally acts to prevent wide oscillations in blood pressure and heart rate, acting on both sympathetic and parasympathetic limbs of the cardiovascular autonomic nervous system. Dysfunction of the arterial baroreflex control on the blood pressure and heart rate has been described in many studies not only in the type I diabetic patients, but also in experimental models of the type I diabetes.

In the diabetic patients, heart rate variability is the most widely used index of the arterial baroreflex function. Some studies in more heterogeneous groups of patients with type 1 diabetes have indicated that: (1) showing lower global heart rate variability; (2) relative increase in the low-frequency component (sympathetic activity) of the heart rate variability; (3) relative reduction in the high-frequency component (parasympathetic activity) of the heart rate variability; and (4) higher ratio of the low frequency to the high-frequency (Lishner et al., 1987; Rosengard-Barlund et al., 2009; Ziegler et al., 2001). Clinical research data have confirmed that arterial baroreflex sensitivity is reduced in type 1 diabetic patients with a wide range of age and diabetic duration (Lefrandt et al., 1999; Weston et al., 1996; Weston et al., 1998; Dalla et al., 2007). More importantly, this attenuated arterial baroreflex function was found in the type 1 diabetic patients without the clinical complications, the alterations of the other autonomic function tests, or the overt autonomic neuropathy (Lefrandt et al., 1999; Rosengard-Barlund et al., 2009). Therefore, it is of note that the reduced arterial baroreflex sensitivity can be an earlier sensitive marker of the cardiovascular autonomic dysfunction in the type 1 diabetic patients.

In order to obtain new insights into human type 1 diabetes, animal models of the type 1 diabetes have been widely used in the biomedical studies focusing on the type 1 diabetes, such as alloxan-induced diabetic rabbits (McDowell et al., 1994b), streptozotocin-induced diabetic rats (Hicks et al., 1998; Maeda et al., 1995; Van et al., 1998; Chen et al., 2008), and calmodulin transgenic OVE26 diabetic mice (Gu et al., 2008). Streptozotocin (STZ)-induced diabetic rat is an animal model of insulin-dependent diabetes usually used to study the cardiovascular alterations including cardiovascular autonomic dysfunction caused by diabetes even if the changes of cardiovascular function in this animal model don't fully match the alterations observed under the clinical type 1 diabetic states (Hicks et al., 1998). In the STZ-induced diabetic rats, the arterial baroreflex dysfunction is presented as early as 5 days after the STZ administration (Maeda et al., 1995). Much evidence has documented that the arterial baroreflex is decreased in all kinds of type 1 diabetic models (Chen et al., 2008; Dall'Ago et al., 1997; De Angelis et al., 2000; Gu et al., 2008; Maliszewska-Scislo et al., 2003; McDowell et al., 1994b; Van et al., 1998).

\subsection{Association of cardiovascular autonomic dysfunction with mortality rate}

30 years ago, Ewing et al (Ewing et al., 1980) first reported that there was a mortality rate of $53 \%$ after 5 years in diabetic patients with abnormal autonomic function, compared with a mortality rate of about $15 \%$ over the 5 year period among diabetic patients without abnormal autonomic function. Thereafter the growing evidence has confirmed that 
cardiovascular autonomic dysfunction is associated with a high risk of cardiac arrhythmias and with sudden death in the diabetic state. A longitudinal study by $\mathrm{O}^{\prime}$ Brien et al (O'Brien et al., 1991) has investigated 5-year survival in 506 randomly selected patients with insulindependent diabetes mellitus. In this study, the cumulative 5-year mortality rate in the diabetic patients with cardiovascular autonomic dysfunction $(27 \%)$ is about 5 -fold more than in the diabetic patients with normal cardiovascular autonomic function (5\%). However, there is no difference in duration of diabetes between the deceased diabetic patients with and without cardiovascular autonomic dysfunction (O'Brien et al., 1991). A meta-analysis (Maser et al., 2003) and the epidemiology of diabetes complication study (Orchard et al., 1996) also showed that cardiovascular autonomic dysfunction could contribute to the increased risk of mortality rate in the individuals with diabetes. In the recent EURODIAB prospective complications study, the researchers have found that cardiovascular autonomic dysfunction is an important risk marker for mortality rate, exceeding the effect of the traditional risk factors (such as age, waist-to-hip ratio, pulse pressure, and non-HDL cholesterol) (Soedamah-Muthu et al., 2008).

Since the diabetic patients are more likely to have many known diabetes-associated risk factors besides cardiovascular autonomic dysfunction (Soedamah-Muthu et al., 2008), the question is whether cardiovascular autonomic dysfunction is an independent risk factor to predict the mortality rate of the diabetic patients. Some studies have addressed this question to minimize the potential interference of other risk factors (for example age, sex, height, smoking, diabetes duration, etc) by matching these variables in the diabetic patients with and without cardiovascular autonomic dysfunction (O'Brien et al., 1991; Orchard et al., 1996; Rathmann et al., 1993). In Rathmann's study (Rathmann et al., 1993), diabetic patients with and without cardiovascular autonomic dysfunction were matched for age, sex, and duration of diabetes. The 8-year survival rate estimate in patients with cardiovascular autonomic dysfunction was $77 \%$ compared with $97 \%$ in those with normal cardiovascular autonomic function in this study (Rathmann et al., 1993). O'Brien et al. have also matched age, sex, and duration of diabetes in the diabetic patients with and without cardiac autonomic dysfunction in their study (O'Brien et al., 1991). They found that the cardiovascular autonomic dysfunction was associated with the mortality rate of the type 1 diabetic patients (O'Brien et al., 1991).

\subsection{Potential mechanisms responsible for cardiovascular autonomic dysfunction- increased mortality rate}

Although many studies mentioned above have confirmed that the cardiovascular autonomic dysfunction is involved in increasing mortality rate of type 1 diabetic patients, we really don't know whether cardiovascular autonomic dysfunction is directly or indirectly responsible for the increased mortality rate. It is possible that several possible mechanisms are involved in this clinical phenomenon.

First, a few clinical studies have reported that some type 1 diabetic patients in good health the previous day are found dead in the morning in an undisturbed bed with no sign of the symptoms (such as sweating and struggle) and negative autopsy results, which is named as the 'dead in bed' syndrome (Tattersall \& Gill, 1991; Weston \& Gill, 1999). One recent clinical study has found that ECG abnormalities including QT prolongation, cardiac rhythm disturbance, and subsequent ventricular tachyarrhythmia appear in the ambulant patients with type 1 diabetes (Gill et al., 2009). The ECG abnormalities can serve as 
principal underlying causes of the 'dead in bed' syndrome (Gill et al., 2009). Cardiovascular autonomic dysfunction itself can link to the QT prolongation and sudden death (Weston \& Gill, 1999). In another study, type 1 diabetic adolescents with impaired cardiovascular autonomic function are associated with the possible development of cardiac arrhythmias and left-ventricular hypertrophy (Karavanaki et al., 2007). In addition, decreased heart rate variability is also a predictive risk factor for ventricular arrhythmia and sudden cardiac death (Kleiger et al., 1987). Loss of cardiac vagal drive combined with loss of baroreceptor reflex sensitivity is thought to mediate the decreased heart rate variability and autonomic instability that exacerbate arrhythmia susceptibility (Binkley et al., 1991). These studies indicate that cardiovascular autonomic dysfunction (decreased heart rate variability and loss of baroreceptor reflex sensitivity) is correlated with the prognosis and mortality in patients with type 1 diabetes via increasing the susceptibility to the lethal arrhythmias.

Second, although cardiovascular autonomic dysfunction is an independent risk factor to predict the mortality rate of the diabetic patients described above, other abnormalities (such as increased stiffness of the vascular walls at the site of the arterial baroreceptors, left ventricular hypertrophy, endothelial dysfunction, renal failure, peripheral neuropathy, etc) usually coexist with cardiovascular autonomic dysfunction in type 1 diabetic patients (Toyry et al., 1997; Lluch et al., 1998; Lefrandt et al., 2010). Therefore, it is possible that the interaction between cardiovascular autonomic dysfunction and other concomitant abnormalities is responsible for the increased mortality rate in type 1 diabetic patients. It has been shown that cardiovascular autonomic function is easily impaired in type 1 diabetic patients with microalbuminuria (renal dysfunction) (Lefrandt et al., 1999; Clarke et al., 1999). $\mathrm{O}^{\prime}$ Brien et al have reported that renal failure-induced mortality rate is higher in type 1 diabetic patients with cardiovascular autonomic dysfunction than in those without cardiovascular autonomic dysfunction (O'Brien et al., 1991). In a 23 year follow-up study, cardiovascular autonomic dysfunction may be involved in a higher mortality rate induced by microalbuminuria in type 1 diabetic patients (Messent et al., 1992). Similarly, renal disease also can partially explicate the cardiovascular autonomic dysfunction-increased mortality rate in patients with diabetes mellitus (Weinrauch et al., 1998; Kim et al., 2009). In addition, using logistic regression analysis, one recent study has addressed the relationship between cardiovascular autonomic dysfunction and other abnormalities in 684 type 1 diabetic patients (Pavy-Le et al., 2010). The research data have shown that retinopathy, peripheral neuropathy, and erectile dysfunction are closely correlated to the severity of the cardiovascular autonomic dysfunction (Pavy-Le et al., 2010). Furthermore, some studies have also found a consistent association between cardiovascular autonomic dysfunction and silent myocardial ischemia, in which the patient's risk coefficient related to the cardiovascular autonomic dysfunction is higher in asymptomatic diabetic patients with silent myocardial ischemia than in those without silent myocardial ischemia (Valensi et al., 2001; Vinik \& Ziegler, 2007; Katz et al., 1999).

Finally, several studies reported the involvement of cardiorespiratory arrest in the mortality of the diabetic patients with cardiovascular autonomic dysfunction (Page \& Watkins, 1978; Bergner \& Goldberger, 2010; Douglas et al., 1981). The research data from Page et al. (Page \& Watkins, 1978) have demonstrated that young diabetic patients with severe cardiovascular autonomic dysfunction can appear to have cardiorespiratory arrest due to the impairment of cardiorespiratory function. The cardiorespiratory arrest may be responsible for the mortality of these diabetic patients (Page \& Watkins, 1978). 


\section{Mechanisms responsible for the reduced baroreflex function in type 1 diabetes}

The arterial baroreflex is a homeostatic mechanism that alters heart rate and blood pressure in response to changes in arterial wall tension detected by the baroreceptors in the carotid sinus and aortic arch. The arterial baroreflex arc includes an afferent limb, a central neural component and autonomic neuroeffector components. As the primary afferent limb of the baroreceptor reflex, baroreceptor neurons sense blood pressure by increasing their discharge (excitation) when arterial blood pressure rises. This excited signal in baroreceptor neurons reaches to the dorsal medial nucleus tractus solitarii (NTS, the first site of baroreceptor neuron contacting with central nervous system), in which the integrated input signal inhibits the efferent sympathetic outflow to the heart and peripheral vascular, and activates efferent parasympathetic activity to the heart those decrease peripheral vascular resistance, heart rate, and arterial blood pressure. Conversely, the baroreceptor afferent signal decreases when arterial blood pressure falls, which reflexly induces an increase in heart rate and arterial blood pressure.

As mentioned above, blunted arterial baroreflex sensitivity is observed in type 1 diabetic patients and animal models. What are the mechanisms responsible for the attenuated arterial baroreflex sensitivity in type 1 diabetes? Every site within the baroreflex arc may be responsible for the depressed baroreflex sensitivity in type 1 diabetes. Therefore, we will discuss the fact that the reduced baroreflex sensitivity results from functional and/or structural changes in the baroreceptors (including nerve terminals and neuron somata), central neural integration, and autonomic efferent component.

\subsection{Role of baroreceptor in the blunted arterial baroreflex in type 1 diabetes}

As the primary afferent limb of the arterial baroreceptor reflex, baroreceptor neurons are pseudo-unipolar neurons (T-shaped neurons) consisting of a cell body existing in the nodose or petrosal ganglia and an initial axon segment. This axon segment bifurcates near the soma into a peripheral process innervating aortic arch and carotid sinus for sensing the alteration of the arterial blood pressure and a central process terminating in the NTS for conveying the afferent signals to the central nervous system. The mechanisms responsible for mediating afferent sensitivity of barosensitive neurons to pressure are complex and not thoroughly understood. The process of translating changes in arterial wall tension into impulse traffic to the NTS involves 2 broad functional steps: 1) mechanotransduction which is governed by the properties of mechanosensitive ion channels in the nerve terminal and the mechanical properties of the coupling of the arterial wall to the sensory terminal; and 2) spike initiation which is governed by the excitability of membrane voltage sensitive ion channels that influence the electrical (cable) properties of the axonal process and cell body. All of these factors could be (and likely are) altered in type 1 diabetes, which can directly affect the arterial baroreflex function.

\subsubsection{Changes of baroreceptor afferent nerve and terminal in type 1 diabetes}

Although some studies have suggested that diabetes-induced postural hypotension results from impairments of afferent baroreceptors and of sympathetic neurons innervating the vascular wall and heart in diabetic patients (Low et al., 1975; Iovino et al., 2011), there is only fragmentary evidence to support this assumption because of the inability of clinical cardiovascular autonomic function tests to separate the role of the afferent, central, and 
efferent components of the arterial baroreflex. In general, the function of the baroreceptor afferent nerve and terminal is investigated by recording the single fiber or multifiber activity of the aortic depressor nerve or carotid sinus nerve in a perfused isolated aortic arch/carotid sinus preparation (do Carmo et al., 2007; Doan et al., 2004; Fazan, Jr. et al., 1997; McDowell et al., 1994b; Reynolds et al., 1994; Reynolds et al., 1999; Xiao et al., 2007; Zhang et al., 2004). However, the baroreceptor function in the diabetic state is studied only in the aortic depressor nerve (Fazan, Jr. et al., 1997; Fazan, Jr. et al., 1999; McDowell et al., 1994b; Reynolds et al., 1999) but not in the carotid sinus nerve (Salgado et al., 2001). This may be because there are only baroreceptor afferent fibers and no chemoreceptor afferent fibers in rat aortic depressor nerve unlike the carotid sinus nerve (Fan et al., 1996; Kobayashi et al., 1999; Sapru \& Krieger, 1977; Sapru et al., 1981). Based on the results from some studies, there is no evidence to show the changes of the aortic depressor nerve activity in STZ-induced type 1 diabetic rats (Fazan, Jr. et al., 1997; Reynolds et al., 1999; Dall'Ago et al., 2002) and alloxaninduced diabetic rabbits (McDowell et al., 1994b), compared to the sham animals. In addition, Gu et al (Gu et al., 2008) have found that the baroreceptor function of the aortic depressor nerve is preserved in the ascending phase of the arterial blood pressure but is blunted in the descending phase of the arterial blood pressure in type 1 diabetic mice. Nevertheless, the results obtained by a new approach, named as cross-spectral analysis, indicate that a significant decrease of the aortic baroreceptor nerve function is observed in anesthetized rats with either short term (10-20 days) or long term (12-18 weeks) STZinduced diabetes (Fazan, Jr. et al., 1999). This new approach uses the magnitude of the transfer function obtained by analyzing the relationship between beat-by-beat time series of mean arterial blood pressure and aortic depressor nerve activity as the index of the aortic baroreceptor nerve function, whose advantage is to evaluate the aortic baroreceptor nerve function under more physiological conditions (Salgado et al., 2001; Fazan, Jr. et al., 1999; deBoer et al., 1987) compared to the arterial blood pressure/aortic depressor nerve activity curve used in other studies (Dall'Ago et al., 2002; Fazan, Jr. et al., 1997; Gu et al., 2008; McDowell et al., 1994b; Reynolds et al., 1999). In addition, Fazan et al have found that the morphological change in the aortic depressor nerve, an afferent arm of the baroreflex may result in the arterial baroreflex impairment in the STZ-induced diabetic rats (Fazan et al., 2006). Therefore, the functional and structural alterations of the baroreceptor afferent nerve in type 1 diabetes still need to be further clarified in future study.

By light, electron, and confocal microscopies, some researchers have identified the aortic baroreceptor terminals in the adventitia of the aortic arch from dogs, rabbits, cats, rats, and mice (Aumonier, 1972; Cheng et al., 1997; Krauhs, 1979; Li et al., 2010). More importantly, Li et al have demonstrated that diabetes induces morphological atrophy of the aortic baroreceptor terminals in type 1 diabetic mice ( $\mathrm{Li}$ et al., 2010). However, there is no report on the functional role of the aortic baroreceptor terminals in sham and type 1 diabetic animals because it is difficult to separate aortic baroreceptor terminals to other tissues (such as smooth muscle and endothelium) in the aortic arch. It is possible that using gene and short hairpin RNA (shRNA) transfection can solve this problem in future study.

\subsubsection{Role of aortic baroreceptor neurons in the arterial baroreflex in the type 1 diabetes}

Many studies have used the responses of blood pressure and heart rate to electrical stimulation of baroreceptor-containing nerve (aortic depressor nerve) for the evaluation of the baroreflex sensitivity in rats (Fan \& Andresen, 1998; Salgado et al., 2007; Tang \& 
Dworkin, 2007). The aortic depressor nerves (the peripheral process of the aortic baroreceptor neuron) are composed of both afferent A-type (myelinated) axons (about 25\%) and C-type (unmyelinated) axons (about 75\%) (Yamasaki et al., 2004). There are very different dynamic sensory discharge characteristics between A-type and C-type baroreceptor afferents. C-type afferents are activated mainly at very high pressure and have lower firing frequencies, irregular discharge patterns (Thoren et al., 1999), and appear to be the primary regulators of tonic baseline levels of arterial blood pressure besides regulating the baroreflex sensitivity (Seagard et al., 1993). A-type afferents have lower pressure thresholds with very stable, proportional firing patterns (Thoren et al., 1999), which are thought to regulate the baroreflex sensitivity but not baseline levels of arterial blood pressure (Seagard et al., 1993). Electrical Stimulation of the rat aortic depressor nerve has several advantages to examine the baroreflex function. First, the rat aortic depressor nerve contains only baroreceptor afferent fibers and no chemoreceptor afferent fibers to transmit the chemoreceptor information (Fan et al., 1996; Kobayashi et al., 1999; Sapru \& Krieger, 1977; Sapru et al., 1981). Second, the baroreflex induced by stimulating rat aortic depressor nerve is measured without the aortic baroreceptor terminals in the reflex arc, which allows us to specifically examine the role of electrical excitability of aortic baroreceptor in the baroreflex function (second process mentioned above). Third, by varying the frequency of stimulus, one can differentially activate A- and C-afferent fibers, and thus evaluate the relative contribution of each to the altered aortic baroreceptor excitability and baroreflex function in STZ-induced diabetes. In our preliminary study, the baroreflex responses of blood pressure and heart rate to the electrical stimulation of the aortic baroreceptor nerve are significantly depressed in STZ-induced diabetic rats (Fig. 1). In addition, our study also found that microinjection of angiotensin II type $1\left(\mathrm{AT}_{1}\right)$ receptor antagonist $(20 \mu \mathrm{M}$ L158,809) into the nodose ganglia significantly improved the baroreflex sensitivity induced by aortic depressor nerve stimulation in STZ-induced diabetic rats (Fig. 1). Simultaneously, $\mathrm{AT}_{1}$ receptor antagonist also normalized the depressed cell excitability in the aortic baroreceptor neurons of STZ-induced diabetic rats (Li \& Zheng, 2011). The fact is that nodose neurons are found to influence the conduction and frequency of the electrical impulses in the baroreceptor central axons projecting to the central nervous system when electrical signals in the baroreceptor peripheral axons reach the nodose neurons (Ducreux et al., 1993). One review paper has concluded that the excitability of vagal afferent neurons has dramatic consequences for the regulation and modulation of vago-vagal reflex (Browning, 2003). Furthermore, Devor (Devor, 1999) has reported that electrical excitability of the soma in the dorsal root ganglia may be required to insure the reliable afferent electrical impulses transmitted to the spinal cord. These results, taken together, demonstrate that the reduced cell excitability of the aortic baroreceptor neurons contributes to the blunted baroreflex sensitivity in STZ-induced diabetic rats.

However, results from reflex experiments evoked by the electrical stimulation need to be tempered because the electrical stimulation technique does not represent a physiological substrate for baroreceptor activation. Thus, arterial baroreflex evoked by changes in arterial blood pressure should be done to further address the role of the aortic baroreceptor neurons in the arterial baroreflex in the type 1 diabetes. Of course, in this approach (blood pressuremediated baroreflex sensitivity), possible alterations in the mechanotransduction process at the baro-sensory nerve terminal may also play a role in the suppressed baroreceptor function in response to pressure changes. 

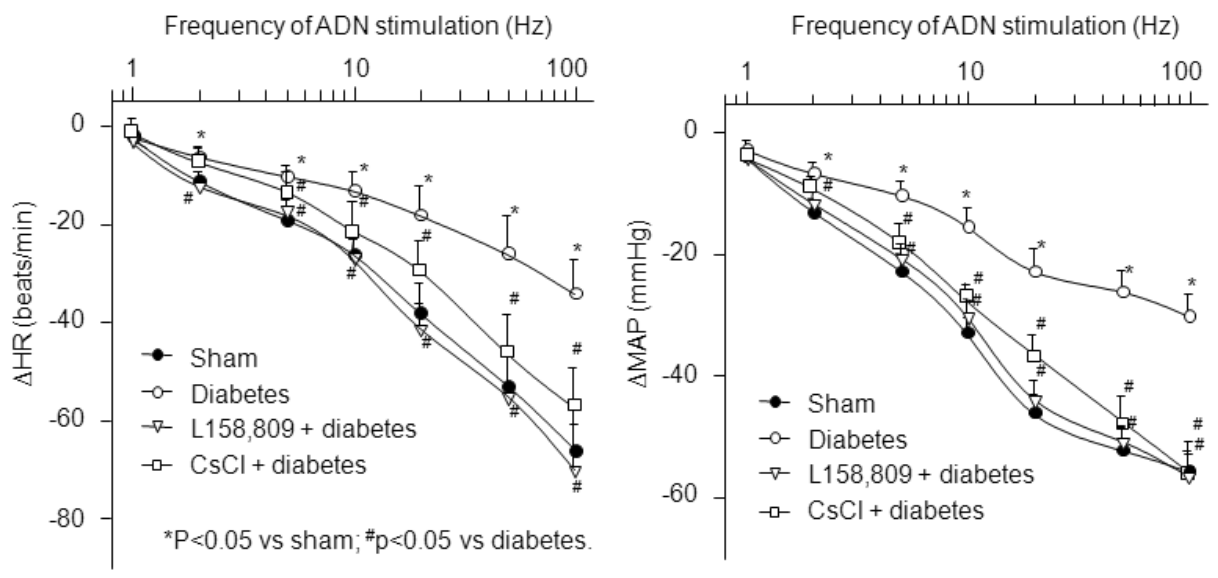

Fig. 1. Reflex $\triangle \mathrm{MAP}$ and $\triangle \mathrm{HR}$ in response to different frequencies of $\mathrm{ADN}$ stimulation in anesthetized sham and STZ-induced diabetic rats ( $n=8$ in each group). L158,809: $\mathrm{AT}_{1}$ receptor antagonist; $\mathrm{CsCl}$ : $\mathrm{HCN}$ channel blocker. $\mathrm{MBP}$, mean blood pressure; $\mathrm{HR}$, heart rate; $\mathrm{ADN}$, aortic depressor nerve.

\subsubsection{Contribution of the HCN channel to the cell excitability of aortic baroreceptor neuron in the type 1 diabetes}

Until now it is controversial whether either severe degenerative changes or neuronal cell loss in sensory and autonomic nervous tissues are found in STZ-induced diabetic animals (Yagihashi, 1997). Apoptotic cell death was reported in the sensory neurons, satellite cells, and Schwann cells from dorsal root ganglia (DRG) of STZ-induced diabetic rats (Russell et al., 1999; Srinivasan et al., 2000). Kogawa et al. also found that apoptotic cell death of DRG neurons and impaired sensory nerve regeneration were induced by sciatic nerve crush in STZ-induced diabetic rats (Kogawa et al., 2000). On the other hand, the findings from Sango et al (Sango et al., 1991; Sango et al., 1995; Sango et al., 1997) indicated no difference in the dissociated neurons from DRG between sham and STZ-induced diabetic mice. Furthermore, some studies have demonstrated that there are no morphological changes of the peripheral nerves (Sharma \& Thomas, 1987) and cell death of the nodose afferent neurons (Sango et al., 2002) in STZ-induced diabetic animals. Our recent study (Tu et al., 2010) also suggests that STZ-induced diabetes does not change the total cell number of the nodose afferent neurons and the ratio of A-/C-type neurons (Fig. 2). These results provide an important piece of information that the parasympathetic reflex dysfunction ( $\mathrm{Li}$ et al., 2008b; Thomas \& Tomlinson, 1993; Ziegler, 1994) in STZ-induced diabetes might be not due to the structural changes in the nodose afferent neurons but most likely due to the functional changes at the cellular and molecular levels.

As everyone knows, many ion channels (such as sodium channels, calcium channels, potassium channels, etc) are responsible for the cell excitation in the excitable cells such as cardiac/skeletal myocytes and neurons including aortic baroreceptor neurons. However, much evidence has indicates that Hyperpolarization-activated cyclic nucleotide-gated $(\mathrm{HCN})$ channels play an important role in the cell excitability of the aortic baroreceptor neurons from sham and STZ-induced diabetic rats. 
HCN channels have been found in various types of cells including cardiac and neuronal cells (DiFrancesco, 1985; DiFrancesco, 1993; Pape, 1996). In these spontaneously exciting cells, HCN channels normally associate to the cardiac pacemaker activity and the neuronal oscillatory behavior (Brown et al., 1979; DiFrancesco, 1993; Kaupp \& Seifert, 2001; Notomi \& Shigemoto, 2004; Pape, 1996; Robinson \& Siegelbaum, 2003). However, HCN channels may have a different role in the nodose ganglion neurons (the non-oscillatory and non-automatic exciting cells) because the nodose neurons are inactive except in response to a depolarizing stimulus generated by their peripheral sensory terminals (Doan \& Kunze, 1999; Li et al., 2008a). In the nodose neurons, the resting membrane potential is about -50 to $-65 \mathrm{mV}$, in which voltage-dependent sodium, calcium, and potassium channels are almost inactivated (Robinson \& Siegelbaum, 2003). The inactivation of these voltage-dependent channels can be recovered to the activation state during the hyperpolarization of the resting membrane potential, which means the number of available voltage-dependent channels for activation is increased if the nodose neurons receive the depolarizing stimulus (Doan \& Kunze, 1999). Inhibition of HCN channels has been shown to hyperpolarize the nodose neurons (increasing the resting membrane potential) and to reduce action potential threshold in response to a depolarizing current stimulation, which suggests that $\mathrm{HCN}$ channels are involved in the cell excitability of the nodose neurons (Doan et al., 2004; Li et al., 2008a). Results from our recent studies (Li et al., 2008a; Li \& Zheng, 2011; Tu et al., 2010) confirm that the HCN current density in A- and C-type aortic baroreceptor neurons from STZinduced diabetic rats is larger than that from the sham rats (Fig. 3). In addition, the resting membrane potential is depolarized and the current threshold induced the action potentials was elevated in the A-/C-type aortic baroreceptor neurons from STZ-induced diabetic rats, compared with that in sham rats (Li et al., 2008a; Li \& Zheng, 2011). Furthermore, HCN channel blockers ( $\mathrm{CsCl}$ and $\mathrm{ZD}-7288)$ lowered the $\mathrm{HCN}$ current density, hyperpolarized the resting membrane potential, and raised the cell membrane excitability in A-/C-type aortic baroreceptor neurons from sham and STZ-induced diabetic rats (Li et al., 2008a; Zhang et al., 2010). These results clearly indicate that the HCN channels are involved in the regulation of aortic baroreceptor neuron excitability. The enhancement of $\mathrm{HCN}$ currents can contribute to the blunted aortic baroreceptor neuron excitability, and subsequently attenuate the arterial baroreflex sensitivity in STZ-induced diabetic rats. This is true because microinjection of $\mathrm{HCN}$ channel blocker ( $5 \mathrm{mM} \mathrm{CsCl}$ ) improves the arterial baroreflex sensitivity induced by the electrical stimulation of the aortic depressor nerve (Fig. 1) (Li et al., 2008b).

Four mammalian genes encoding HCN channel isoforms (HCN1, HCN2, HCN3, and HCN4) have been identified (Doan et al., 2004; Ishii et al., 1999; Ludwig et al., 1998; Santoro et al., 1998; Vaccari et al., 1999). In cell lines transfected HCN isoform cDNA, electrophysiological studies have shown that each channel isoform is activated by membrane hyperpolarization with distinct activation kinetics (Ludwig et al., 1999; Moosmang et al., 2001; Qu et al., 2002; Santoro et al., 1998). Activation of the HCN channels is also directly modulated by cAMP, which is dependent on the HCN channel isoform (Stieber et al., 2003; Wainger et al., 2001; Wang et al., 2002). HCN channels are activated with the different activation rates in this order: $\mathrm{HCN} 1>\mathrm{HCN} 2>\mathrm{HCN} 3>\mathrm{HCN} 4$ (Accili et al., 2002; Altomare et al., 2001; Moosmang et al., 2001; Stieber et al., 2003; Stieber et al., 2005). HCN1 and HCN3 are only weakly affected by cAMP whereas HCN2 and HCN4 are very sensitive to cAMP (Accili et al., 2002; Stieber et al., 2005; Wahl-Schott \& Biel, 2009; Wang et al., 2001). Our studies (Li et al., 2008a; Tu et al., 2010) have found that a fast-activated and cAMP- 
A.

Sham NG

RT97

IB4

Merged

DAPI
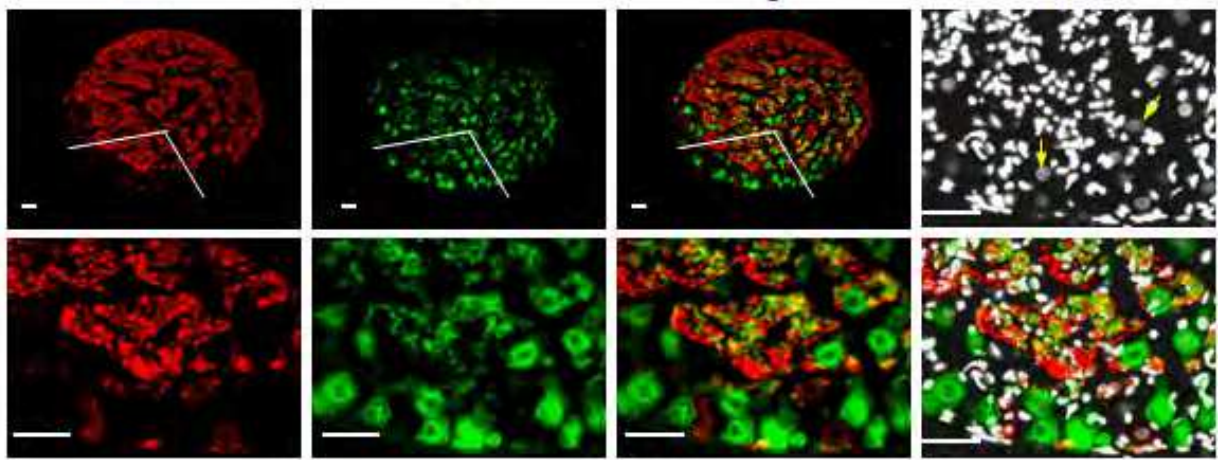

Diabetic NG
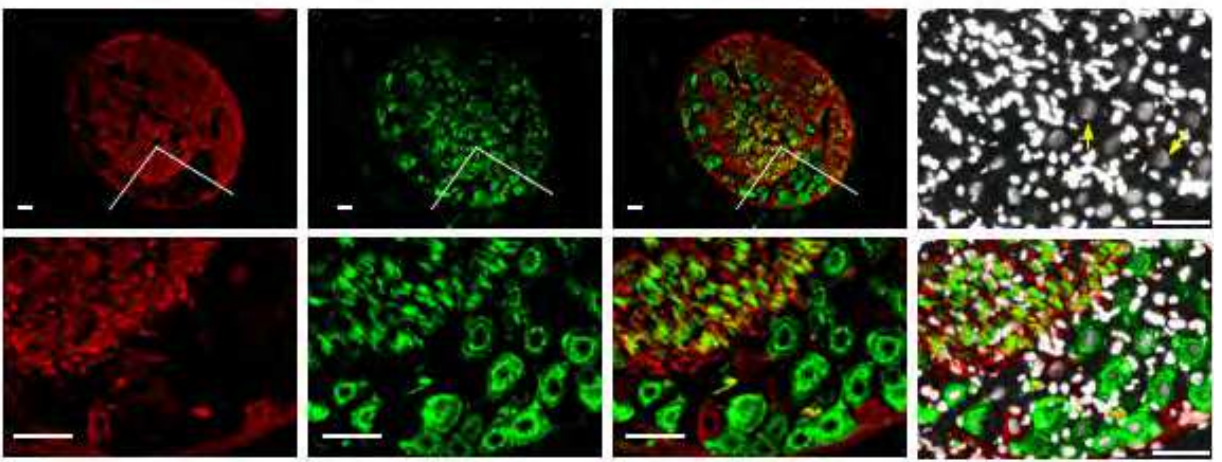

B.

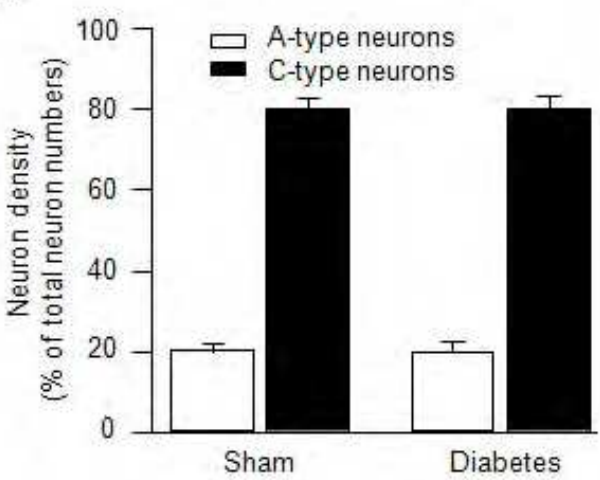

C.

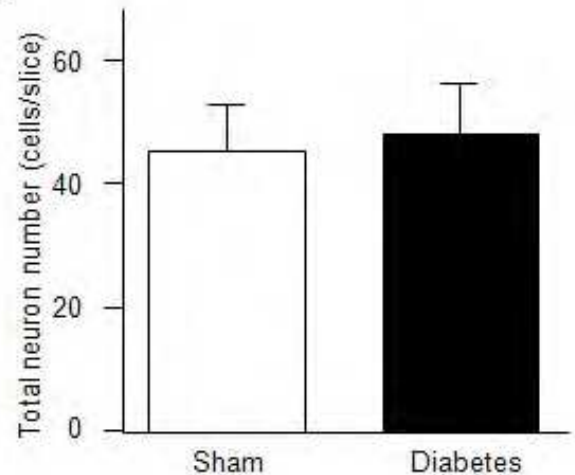

Fig. 2. Ratio of A-type/C-type neurons (A and B) and total neuron number (C) in nodose ganglia from sham and STZ-induced diabetic rats. Calibration bar: $100 \mu \mathrm{m}$. RT97, A-type neuron marker; IB4, C-type neuron marker; DAPI, cell nucleus marker. Yellow arrows indicate nodose neurons in DAPI staining (Adapted and reprinted from Tu et al., 2010, page 42, with permission from Elsevier) 
A. A-type neuron

Sham

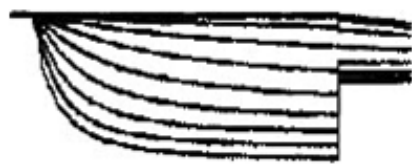

Diabetes

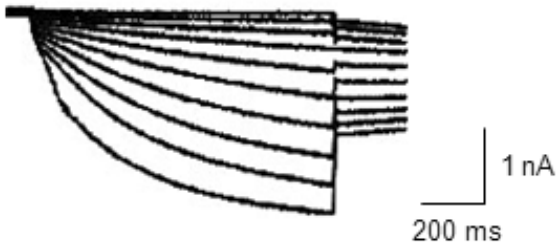

B. C-type neuron

Sham

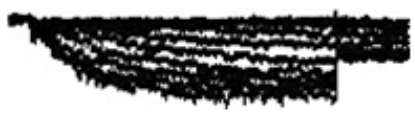

Diabetes

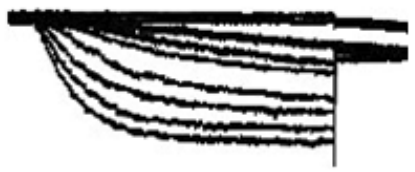

$-40 \mathrm{mV}$

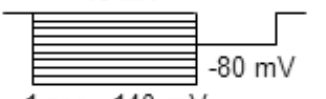

$1 \mathrm{sec},-140 \mathrm{mV}$

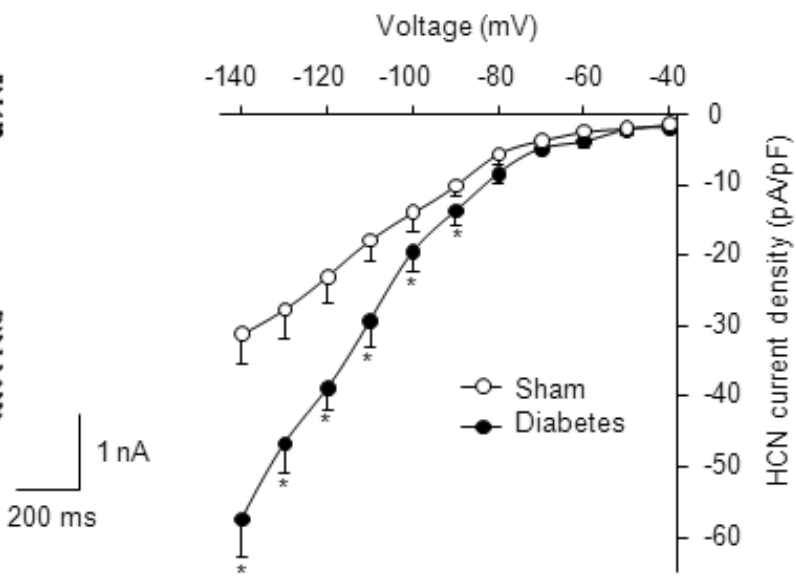

Voltage $(\mathrm{mV})$

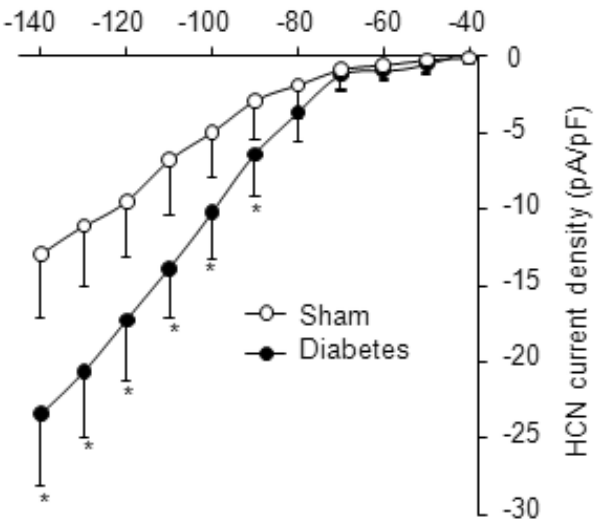

Fig. 3. Original HCN current recording and current density-voltage curves in A- and C-type neurons from sham and STZ-induced diabetic rats. ${ }^{*} \mathrm{P}<0.05$ vs. sham rats (Reprinted from Tu et al., 2010, page 48, with permission from Elsevier).

insensitive $\mathrm{HCN}$ current is induced in sham A-type aortic baroreceptor neurons whereas a slow-activated and cAMP-sensitive $\mathrm{HCN}$ current is induced in sham C-type aortic baroreceptor neurons. From these electrophysiological results, we can imagine that there is a differential distribution of the HCN channel isoforms in the A- and C-type aortic baroreceptor neurons. Data from immunofluorescent double staining also show that HCN1, $\mathrm{HCN} 3$, and HCN4 are expressed in sham A-type nodose neurons, whereas HCN2, HCN3, and HCN4 are expressed in sham C-type nodose neurons (Li et al., 2008a; Tu et al., 2010). Based on these results, it is reasonable to assume that there are marked different activation kinetics and cAMP sensitivity of $\mathrm{HCN}$ channels between A-fiber neurons and C-fiber neurons, which might be due to the neuron cell-specific expression of $\mathrm{HCN}$ channel isoforms. 
Our studies further demonstrate that diabetes enhances the $\mathrm{HCN}$ currents and the expression of $\mathrm{HCN} 1, \mathrm{HCN} 2$, and $\mathrm{HCH} 3$ channel proteins in A-type aortic baroreceptor neurons (Li et al., 2008a; Tu et al., 2010). Overexpression of HCN1, HCN2, and HCN3 but not $\mathrm{HCN} 4$ channel isoforms can link to the enhanced HCN currents, the slow-activated HCN channel kinetics, and the increased cAMP-sensitivity of HCN channels in diabetic A-type aortic baroreceptor neurons (Li et al., 2008a; Tu et al., 2010). Although diabetes also increases the $\mathrm{HCN}$ currents and the expression of $\mathrm{HCN} 2$ and HCN3 channel proteins in C-type aortic baroreceptor neurons, diabetes does not change the activation kinetics and the cAMP sensitivity of the HCN channels in C-type aortic baroreceptor neurons due to no expression of HCN1 channel in diabetic C-type aortic baroreceptor neurons (Li et al., 2008a; Tu et al., 2010). From these results, we propose that HCN currents are markedly enhanced via increasing the numbers of HCN channels and sensitivity of HCN channels to cAMP in the aortic baroreceptor neurons. The enhanced HCN currents can contribute to the depressed neuron excitability in diabetic aortic baroreceptor neurons. However, we do realize that these data cannot explain why diabetes induces the different changes of HCN channel protein expression and cannot identify the contribution of the various $\mathrm{HCN}$ channel isoforms to the enhanced HCN currents in diabetic A- and C-type aortic baroreceptor neurons.

\subsubsection{Regulation of the angiotensin II-superoxide signaling on the $\mathrm{HCN}$ channel in the type 1 diabetes}

Angiotensin II, an endogenous peptide, has been thought to be a prime candidate in the regulation of the HCN channel function and cell excitability in the diabetic state. It is known that circulating and tissue angiotensin II concentrations are elevated in human and animals with diabetes (Frustaci et al., 2000; Sechi et al., 1994; Shimoni \& Liu, 2004). Previous autoradiographic study has identified a high density of angiotensin II receptor binding sites over the nodose neurons (Allen et al., 1988). Widdop, et al. provided evidence for the direct neuronal effects of angiotensin II on the vagal afferent neurons (Widdop et al., 1992). Indeed, our research data not only confirm $\mathrm{AT}_{1}$ and $\mathrm{AT}_{2}$ receptors exist in nodose neuronal cells, but also indicate that exogenous angiotensin II enhances the HCN currents and subsequently reduces cell excitability in the aortic baroreceptor neurons from normal rats (Zhang et al., 2010). This is via NADPH oxidase-derived superoxide because a specific HCN channel blocker blunts the inhibitory effect of the exogenous angiotensin II on action potentials (Zhang et al., 2010). More importantly, angiotensin II concentration and protein expression of $\mathrm{AT}_{1}$ receptors are increased in the nodose neuronal cells from STZ-induced diabetic rats (Li \& Zheng, 2011). At the same time, mRNA expression of $\mathrm{AT}_{1}$ receptors measured by single cell real-time PCR technique is enhanced in the aortic baroreceptor neuron cells from the STZ-induced diabetic rats ( $\mathrm{Li} \&$ Zheng, 2011). In addition, $\mathrm{AT}_{1}$ receptor antagonist (losartan) significantly normalizes the enhanced HCN currents and the attenuated cell excitability (including depolarization of the resting membrane potential, fall in the input resistance, and decrease in the action potential number) in the aortic baroreceptor neurons induced by diabetes (Li \& Zheng, 2011) or exogenous angiotensin II (Zhang et al., 2010). Furthermore, angiotensin $\mathrm{II}_{-} \mathrm{AT}_{1}$ receptor is also involved in the attenuated arterial baroreflex sensitivity in STZ-induced diabetic rats (Fig. 1) (Li et al., 2008b). Based on these results, it is reasonable to assume that elevation of local angiotensin II level can blunt the membrane excitability of the aortic baroreceptor neurons via enhancement of the HCN currents, and consequently attenuate the aortic baroreflex function in the type 1 diabetes. 
Above results suggest that elevation of local tissue angiotensin II plays an important role on the enhanced HCN channel activity and the blunted cell excitability in the AB neurons in diabetes. However, it is unclear how angiotensin II and its antagonist within an isolated aortic baroreceptor neuron from diabetic rat interact with $\mathrm{AT}_{1}$ receptor to affect the $\mathrm{HCN}$ channel activity and cell excitability. Classical viewpoint about the effects of angiotensin II binding with $\mathrm{AT}_{1}$ receptor is that angiotensin II binds with $\mathrm{AT}_{1}$ receptor at the cell membrane, and following the phosphorylation of the $\mathrm{AT}_{1}$ receptor, angiotensin II induces intracellular responses via activating intracellular downstream signal transduction. However, Zhuo, et al. (Zhuo et al., 2002) have found that there is substantial intracellular accumulation of angiotensin II in renal cortical endosomes during angiotensin II-dependent hypertension via an $\mathrm{AT}_{1}$ receptor-mediated process. Recent studies have shown that intracellular administration of angiotensin II increases the peak inward calcium current density and decreases the junctional conductance via intracellular angiotensin II receptors in cardiac myocytes (De Mello, 2003; De Mello \& Monterrubio, 2004). Intracellular treatment of losartan (a selective $\mathrm{AT}_{1}$ receptor antagonist) abolishes the effect of intracellular angiotensin II (Allen et al., 1988; Bacal \& Kunze, 1994). Based on these studies, we reason that diabetesinduced elevation of intracellular angiotensin II concentration in the nodose neurons contributes to the enhanced $\mathrm{HCN}$ channel activity and the blunted cell excitability in the $\mathrm{AB}$ neurons in diabetes. This viewpoint is confirmed by our observation that intracellular administration of losartan (added to the recording pipette solution) decreased the HCN current density and increased the cell excitability in the AB neurons from diabetic rats (Li \& Zheng, 2011). Therefore, it is possible there is an intracellular angiotensin II production system in the nodose ganglion tissue. Of course, it would be optimal to measure intracellular angiotensin II concentration in the aortic baroreceptor neurons, but there is no appropriate measurement for it so far due to insufficient cellular material of tiny nodose ganglia. This issue needs to be confirmed by further study.

Growing evidence has shown that the $\mathrm{AT}_{1}$ and $\mathrm{AT}_{2}$ receptors are defined on the basis of their opposite pharmacological and biochemical effects (Levy, 2004). Activation of $\mathrm{AT}_{1}$ receptors mainly results in vasoconstriction, augmentation of cardiac contractility, cell proliferation, vascular and cardiac hypertrophy, oxidative stress, and inhibition of the neuronal potassium currents (Gelband et al., 1999; Levy, 2004; Sumners et al., 1996). On the other hand, stimulation of $\mathrm{AT}_{2}$ receptors induces vasodilation, anti-growth, antihypertrophy, and enhancement of the neuronal potassium currents (Horiuchi et al., 1999; Kang et al., 1995; Martens et al., 1996; Matsubara, 1998; Siragy, 2000). Although $\mathrm{AT}_{2}$ receptors are expressed in the rat nodose neurons, activation of $\mathrm{AT}_{2}$ receptors does not affect the activation of $\mathrm{HCN}$ channels because $\mathrm{AT}_{2}$ receptor antagonist (PD123,319) does not alter the effect of angiotensin II on the HCN currents (Zhang et al., 2010). Until now there is no study to explain this result, but it is possible that many factors (such as species, tissue, channel sensitivity, etc) are responsible for this discrepancy.

Now the question is how angiotensin II regulates the activation of $\mathrm{HCN}$ channels and what is the downstream of angiotensin $\mathrm{II}_{-} \mathrm{AT}_{1}$ receptor. $\mathrm{NADPH}$ oxidase has been considered as a main source of intracellular superoxide in many tissues (Cifuentes et al., 2000; Franco et al., 2003; Gao et al., 2004; Griendling et al., 2000; Li et al., 2007; Schieffer et al., 2000). NADPH oxidase is a multicomponent enzyme composed of three cytosolic subunits (p40phox, p47phox, and p67phox), two membrane-associated subunits (gp91phox and p22phox), and the small Gproteins (Rac and Rap1a) (Kim \& Iwao, 2000; Lassegue \& Clempus, 2003). Angiotensin II significantly activates NADPH oxidase via $\mathrm{AT}_{1}$ receptors, resulting in the superoxide 
production (Touyz \& Berry, 2002). In the nodose ganglia from STZ-induced diabetic rats, the protein expression of the NADPH oxidase components (gp91phox, p22phox, p40phox, p47phox, and p67phox) is elevated, compared to sham rats (Li \& Zheng, 2011). In addition, NADPH oxidase inhibitor or superoxide scavenger significantly improves the superoxide overproduction, the enhanced HCN currents, and the lowered membrane excitability induced by exogenous angiotensin II (Zhang et al., 2010) or diabetes (Li \& Zheng, 2011). These results strongly indicate that NADPH-derived superoxide can mediate the effect of endogenous angiotensin II on the HCN channels and membrane excitability in diabetic rat aortic baroreceptor neurons.

\subsubsection{Role of other channels in the aortic baroreceptor neuron in the type 1 diabetes}

Using patch-clamp technique, all major voltage-gated ion channels including channels subunits are recorded in the nodose neurons, such as sodium channels (tetrodotoxinsensitive and tetrodotoxin-resistant sodium channels), calcium channels (N-type, L-type, T/R-type, and other type calcium channels), and potassium channels (4-aminopyridinesensitive, tetraethylammonium-sensitive, and calcium-activated potassium channels) (Lancaster et al., 2002; Li et al., 2005; Li \& Schild, 2006; Schild \& Li, 2001). These channels all are involved in the initiation and formation of the action potential and affect the nodose neuron excitability. Angiotensin II is known to modulate the calcium channel kinetics in the nodose neurons (Bacal \& Kunze, 1994; Moreira et al., 2005). However, until now we did not obtain any information about the changes of these channels in the aortic baroreceptor neurons in the type 1 diabetes. Therefore, the role of these channels in the diabetic baroreceptor neurons remains to be revealed.

\subsection{Involvement of the central neural component in the blunted arterial baroreflex in type 1 diabetes}

Central neural integration of the input signals from the baroreceptors usually occurs at the level of nucleus tractus solitarii and rostral ventrolateral medulla (Spyer et al., 1997). Although many studies have shown that diabetes causes a variety of functional and morphological disorders in the central nervous system (including hippocampus, cortex, and cerebellum) (Biessels et al., 1999; Selvarajah \& Tesfaye, 2006; Mooradian, 1997a; Mooradian, 1997b; Guven et al., 2009), the role of the central neural component in the blunted arterial baroreflex in type 1 diabetes is less well documented. One recent study from $\mathrm{Gu}$, et al (Gu et al., 2008) suggests that a deficit of the central neural component contributes to the attenuation of arterial baroreflex in OVE26 type 1 diabetic mice. This is because they found that stimulation of the aortic depressor nerve induced a lesser magnitude of bradycardia in OVE26 type 1 diabetic mice as compared to sham mice, but the bradycardic response to vagal efferent stimulation was enhanced (Gu et al., 2008). Immunoreactive study has shown that reduced c-Fos expression (an indicator of early cellular response to many extracellular signals) in the nucleus tractus solitarii links to the attenuated arterial baroreflex sensitivity in STZ-induced diabetic rats (Gouty et al., 2001). In addition, Chen, et al (Chen et al., 2008) have reported that neural firing activity of the nucleus tractus solitarii in STZ-induced diabetes is reduced, which is involved in the impaired arterial baroreflex function in STZ-induced diabetic rats. Furthermore, a chronic intracerebroventricular infusion of leptin (a hormone produced by fat cells and improving glucose utilization, Minokoshi et al., 1999; Wang et al., 1999) totally normalizes the impaired arterial baroreflex sensitivity in STZ-induced diabetic 
rats (do Carmo et al., 2008), which indirectly suggests that impairment of the central neural system is associated with the arterial baroreflex dysfunction in type 1 diabetes. These findings allow us to assume the involvement of the impaired central neural integration in the blunted arterial baroreflex in type 1 diabetes even though there is no report focusing on the mechanisms responsible for the impairment of the central neural component of the arterial baroreflex.

\subsection{Participation of autonomic neuroeffector component in the blunted arterial baroreflex in type 1 diabetes}

The autonomic neuroeffector component of the arterial baroreflex includes intracardiac ganglia, parasympathetic efferents, and sympathetic efferents. Morphological studies have shown that there is a remarkable structural remodeling of the intracardiac ganglia (such as cellular contraction, cytoplasmic condensation, degenerated axons, reduced cell size and number) in STZ-induced diabetic rats (Kamal et al., 1991; Lund et al., 1992), mice (Lin et al., 2010), and diabetic patients (Tsujimura et al., 1986). Biochemical studies also found a decrease in acetylcholine (a neurotransmitter in both the central and parasympathetic nervous system) concentration in alloxan-induced diabetic rats (Kuntscherova \& Vlk, 1970) and a reduced choline acetyltransferase activity (an enzyme producing acetylcholine) in the hearts of the STZ-induced diabetic rats (Lund et al., 1992). In addition, the function of the parasympathetic (vagal) efferent is reduced in STZ-induced diabetic rats (Maeda et al., 1995; Yagihashi, 1995). However, functional studies have reported normal, reduced, or enhanced heart rate response to vagal efferent nerve stimulation in diabetic animal models (Dall'Ago et al., 2007; de et al., 2002; Lin et al., 2010; Maeda et al., 1995; McDowell et al., 1994a). This discrepancy might be due to different animal species, experimental diabetic animal models, and time course of development of diabetes. Therefore, further studies are needed to explore whether the altered efferent component of the arterial baroreflex is responsible for the arterial baroreflex dysfunction in type 1 diabetes besides the arterial baroreceptor and central integration.

\section{Conclusion}

As a homeostatic mechanism, the arterial baroreflex normally alters heart rate and blood pressure in response to changes in arterial wall tension detected by the baroreceptors in the carotid sinus and aortic arch. As illustrated by the above evidence, arterial baroreflex impairment, a characteristic of the autonomic cardiovascular dysfunction is a frequent complication in type 1 diabetic patients and animal models. The arterial baroreflex dysfunction not only is an independent predictor for mortality of the type 1 diabetic patients, but also is associated with a poor prognosis and bad quality of life in the type 1 diabetic patients.

Although the mechanisms responsible for attenuated arterial baroreflex function in the type 1 diabetes are not yet fully understood, any part of the arterial baroreflex arc including an afferent limb, a central neural component, and an autonomic neuroeffector component can contribute to the arterial baroreflex dysfunction in the type 1 diabetic state. Especially at the level of the afferent limb, recent studies have revealed that aortic depressor nerve discharge and excitability of aortic baroreceptor neurons are blunted in the type 1 diabetic animals. HCN channels are significantly suppressed in the aortic baroreceptor neurons and are involved in the blunted baroreceptor neuron excitability in the type 1 diabetes. Angiotensin 
$\mathrm{II} / \mathrm{AT}_{1}$ receptor-NADPH oxidase-superoxide signaling regulates this alteration of the HCN channels in the aortic baroreceptor neurons and consequently decreases the arterial baroreflex function. In addition, we also consider that angiotensin II/ $\mathrm{AT}_{1}$ receptor-NADPH oxidase-superoxide signaling affects the changes in the central neural and autonomic neuroeffector components beyond the afferent limb of the arterial baroreflex arc. These studies provide new information on the mechanisms underlying the impaired arterial baroreflex in the type 1 diabetes and unveil important pharmacological and genomic targets for improving the arterial baroreflex function and reducing the mortality in the type 1 diabetes.

\section{Acknowledgments}

This work was supported by a Scientist Development Grant from American Heart Association National Center (award no. 0730108N) to Yu-Long Li.

\section{References}

Accili, E.A.; Proenza, C.; Baruscotti, M. \& DiFrancesco, D. (2002). From funny current to HCN channels: 20 years of excitation. News in Physiological Sciences, Vol.17, No. 1, (February, 2002), pp. 32-37, ISSN 1548-9213

Allen, A.M.; Lewis, S.J.; Verberne, A.J. \& Mendelsohn, F.A. (1988). Angiotensin receptors and the vagal system. Clinical \& Experimental Hypertension. Part A, Vol.10, No. 6, (August, 1988), pp. 1239-1249, ISSN 1064-1963

Altomare, C.; Bucchi, A.; Camatini, E.; Baruscotti, M.; Viscomi, C.; Moroni, A. \& DiFrancesco, D. (2001). Integrated allosteric model of voltage gating of HCN channels. Journal of General Physiology, Vol. 117, No. 6, (June, 2001), pp. 519-532, ISSN 0022-1295

Aumonier, F.J. (1972). Histological observations on the distribution of baroreceptors in the carotid and aortic regions of the rabbit, cat and dog. Acta Anatomica (Basel), Vol. 82, No. 1, pp. 1-16, ISSN 0001-5180

Bacal, K. \& Kunze, D.L. (1994). Dual effects of angiotensin II on calcium currents in neonatal rat nodose neurons. Journal of Neuroscience, Vol. 14, No. 11, (Novermber, 1994), pp. 7159-7167, ISSN 0270-6474

Bergner, D.W. \& Goldberger, J.J. (2010). Diabetes mellitus and sudden cardiac death: what are the data? Cardiology Journal, Vol. 17, No. 2, (March, 2010), pp. 117-129, ISSN 1897-5593

Biessels, G.J.; Cristino, N.A.; Rutten, G.J.; Hamers, F.P.; Erkelens, D.W. \& Gispen, W.H. (1999). Neurophysiological changes in the central and peripheral nervous system of streptozotocin-diabetic rats. Course of development and effects of insulin treatment. Brain, Vol. 122, No. 4, (April, 1999), pp. 757-768, ISSN 0006-8950

Binkley, P.F.; Nunziata, E.; Haas, G.J.; Nelson, S.D. \& Cody, R.J. (1991). Parasympathetic withdrawal is an integral component of autonomic imbalance in congestive heart failure: demonstration in human subjects and verification in a paced canine model of ventricular failure. Journal of the American College of Cardiology, Vol. 18, No. 2, (August, 1991), pp. 464-472, ISSN 0735-1097

Brown, H.F.; DiFrancesco, D. \& Noble, S.J. (1979). How does adrenaline accelerate the heart? Nature, Vol. 280, No. 5719, (July, 1979), pp. 235-236, ISSN 0028-0836 
Browning, K.N. (2003). Excitability of nodose ganglion cells and their role in vago-vagal reflex control of gastrointestinal function. Current Opinion in Pharmacology, Vol. 3, No. 6, (December, 2003) pp. 613-617, ISSN 1471-4892

Chen, H.Y.; Wu, J.S.; Chen, J.J. \& Cheng, J.T. (2008). Impaired regulation function in cardiovascular neurons of nucleus tractus solitarii in streptozotocin-induced diabetic rats. Neuroscience Letters, Vol. 431, No. 2, (January, 2008), pp. 161-166, ISSN 0304-3940

Cheng, Z.; Powley, T.L.; Schwaber, J.S. \& Doyle, F.J. (1997). A laser confocal microscopic study of vagal afferent innervation of rat aortic arch: chemoreceptors as well as baroreceptors. Journal of the Autonomic Nervous System, Vol. 67, No. 1-2, (December, 1997), pp. 1-14, ISSN 0165-1838

Cifuentes, M.E.; Rey, F.E.; Carretero, O.A. \& Pagano, P.J. (2000). Upregulation of p67(phox) and gp91(phox) in aortas from angiotensin II-infused mice. American Journal of Physiology Heart and Circulatory Physiology, Vol. 279, No. 5, pp. (November, 2000), H2234-H2240, ISSN 0363-6135

Clarke, C.F.; Eason, M.; Reilly, A.; Boyce, D. \& Werther, G.A. (1999). Autonomic nerve function in adolescents with Type 1 diabetes mellitus: relationship to microalbuminuria. Diabetic Medicine, Vol. 16, No. 7, (July, 1999), pp. 550-554, ISSN 0742-3071

Dall'Ago, P.; D'Agord, S.B., Da, S.V.O.; Werner, J.; da Silva Soares, P.P.; de, A.K. \& Irigoyen, M.C. (2007). Parasympathetic dysfunction is associated with baroreflex and chemoreflex impairment in streptozotocin-induced diabetes in rats. Autonomic Neuroscience, Vol. 131, No. 1-2, (January, 2007), pp. 28-35, ISSN 1566-0702

Dall'Ago, P.; Fernandes, T.G.; Machado, U.F.; Bello, A.A. \& Irigoyen, M.C. (1997). Baroreflex and chemoreflex dysfunction in streptozotocin-diabetic rats. Brazilizan Journal of Medical Biological Research, Vol. 30, No. 1, (January, 1997), pp. 119-124, ISSN 0100879X

Dall'Ago, P.; Silva, V.O.; De Angelis, K.L.; Irigoyen, M.C.; Fazan, R.Jr. \& Salgado, H.C. (2002). Reflex control of arterial pressure and heart rate in short-term streptozotocin diabetic rats. Brazilizan Journal of Medical Biological Research, Vol. 35, No. 7, (July, 2002), pp. 843-849, ISSN 0100-879X

Dalla, P.R.; Bechtold, S.; Bonfig, W.; Putzker, S.; Kozlik-Feldmann, R.; Schwarz, H.P. \& Netz, H. (2007). Impaired short-term blood pressure regulation and autonomic dysbalance in children with type 1 diabetes mellitus. Diabetologia, Vol. 50, No. 12, (December, 2007), pp. 2417-2423, ISSN 0012-186X

De Angelis, K.L.; Oliveira, A.R.; Dall'Ago, P.; Peixoto, L.R.; Gadonski, G.; Lacchini, S.; Fernandes, T.G. \& Irigoyen, M.C. (2000). Effects of exercise training on autonomic and myocardial dysfunction in streptozotocin-diabetic rats. Brazilizan Journal of Medical Biological Research. Vol. 33. No. 6, (June, 2000), pp. 635-641, ISSN 0100-879X

De Mello, W.C. (2003). Further studies on the effect of intracellular angiotensins on heart cell communication: on the role of endogenous angiotensin II. Regulatory Peptides, Vol. 115, No. 1, (August, 2003), pp. 31-36, ISSN 0167-0115

De Mello, W.C. \& Monterrubio, J. (2004). Intracellular and extracellular angiotensin II enhance the L-type calcium current in the failing heart. Hypertension, Vol. 44, No. 3, (September, 2004), pp. 360-364, ISSN 0194-911X 
De, A.K.; Schaan, B.D.; Maeda, C.Y.; Dall'Ago, P.; Wichi, R.B. \& Irigoyen, M.C. (2002). Cardiovascular control in experimental diabetes. Brazilizan Journal of Medical Biological Research, Vol. 35, No. 9, (September, 2002), pp. 1091-1100, ISSN 0100-879X

deBoer, R.W.; Karemaker, J.M. \& Strackee, J. (1987). Hemodynamic fluctuations and baroreflex sensitivity in humans: a beat-to-beat model. American Journal of Physiology, Vol. 253, No. 3, (September, 1987), pp. H680-H689, ISSN 0002-9513

Devor, M. (1999). Unexplained peculiarities of the dorsal root ganglion. Pain, Vol. Suppl 6, (August, 1999), pp. S27-S35, ISSN 0304-3959

DiFrancesco, D. (1985). The cardiac hyperpolarizing-activated current, if. Origins and developments. Progress in Biophysics and Molecular Biology, Vol. 46, No. 3, pp. 163183, ISSN 0079-6107

DiFrancesco, D. (1993). Pacemaker mechanisms in cardiac tissue. Annual Review of Physiology, Vol. 55, pp. 455-472, ISSN 0066-4278

do Carmo, J.M.; Hall, J.E. \& da Silva, A.A. (2008). Chronic central leptin infusion restores cardiac sympathetic-vagal balance and baroreflex sensitivity in diabetic rats. American Journal of Physiology Heart and Circulatory Physiology, Vol. 295, No. 5, (November, 2008), pp. H1974-H1981, ISSN 0363-6135

do Carmo, J.M., Huber, D.A.; Castania, J.A.; Fazan, V.P.; Fazan, R.Jr. \& Salgado, H.C. (2007). Aortic depressor nerve function examined in diabetic rats by means of two different approaches. Journal of Neuroscience Methods, Vol. 161, No. 1, (March, 2007), pp. 17-22, ISSN 0165-0270

Doan, T.N. \& Kunze, D.L. (1999). Contribution of the hyperpolarization-activated current to the resting membrane potential of rat nodose sensory neurons. Journal of Physiology, Vol. 514, No. 1, (January, 1999), pp. 125-138, ISSN 0022-3751

Doan, T.N.; Stephans, K.; Ramirez, A.N.; Glazebrook, P.A.; Andresen, M.C. \& Kunze, D.L. (2004). Differential distribution and function of hyperpolarization-activated channels in sensory neurons and mechanosensitive fibers. Journal of Neuroscience, Vol. 24, No. 13, (March, 2004), pp. 3335-3343, ISSN 0270-6474

Douglas, N.J.; Campbell, I.W.; Ewing, D.J.; Clarke, B.F. \& Flenley, D.C. (1981). Reduced airway vagal tone in diabetic patients with autonomic neuropathy. Clinical Science (London), Vol. 61, No. 5, (November, 1981), pp. 581-584, ISSN 0143-5221

Ducreux, C.; Reynaud, J.C. \& Puizillout, J.J. (1993). Spike conduction properties of T-shaped $\mathrm{C}$ neurons in the rabbit nodose ganglion. Pflugers Archive, Vol. 424, No. 3-4, (August, 1993), pp. 238-244, ISSN 0031-6768

Ewing, D.J.; Campbell, I.W. \& Clarke, B.F. (1980). The natural history of diabetic autonomic neuropathy. Quarterly Journal of Medicine, Vol. 49, No. 1, pp. 95-108, ISSN 0033-5622

Fan, W. \& Andresen, M.C. (1998). Differential frequency-dependent reflex integration of myelinated and nonmyelinated rat aortic baroreceptors. American Journal of Physiology, Vol. 271, No. 2, (August, 1998), pp. H632-H640, ISSN 0002-9513

Fan, W.; Reynolds, P.J. \& Andresen, M.C. (1996). Baroreflex frequency-response characteristics to aortic depressor and carotid sinus nerve stimulation in rats. American Journal of Physiology, Vol. 271, No. 6, (December, 1996), pp. H2218-H2227, ISSN 0002-9513

Fazan, R.Jr.; Ballejo, G.; Salgado, M.C.; Moraes, M.F. \& Salgado, H.C. (1997). Heart rate variability and baroreceptor function in chronic diabetic rats. Hypertension, Vol. 30, No. 3, (September, 1997), pp. 632-635, ISSN 0194-911X 
Fazan, R.Jr.; Dias da Silva, V.J. \& Salgado, H.C. (1999). Baroreceptor function in streptozotocin-induced diabetes in rats: a spectral analysis approach. Journal of Hypertension, Vol. 18, pp. S136, ISSN 0263-6352

Fazan, V.P.; Salgado, H.C. \& Barreira, A.A. (2006). Aortic depressor nerve myelinated fibers in acute and chronic experimental diabetes. American Journal of Hypertension, Vol. 19, No. 2, (February, 2006), pp. 153-160, ISSN 0895-7061

Franco, M.C.; Akamine, E.H.; Di Marco, G.S.; Casarini, D.E.; Fortes, Z.B.; Tostes, R.C.; Carvalho, M.H. \& Nigro, D. (2003). NADPH oxidase and enhanced superoxide generation in intrauterine undernourished rats: involvement of the reninangiotensin system. Cardiovascular Research, Vol. 59, No. 3, (September, 2003), pp. 767-775, ISSN 0008-6363

Frustaci, A.; Kajstura, J.; Chimenti, C.; Jakoniuk, I.; Leri, A.; Maseri, A.; Nadal-Ginard, B. \& Anversa, P. (2000). Myocardial cell death in human diabetes. Circulation Research, Vol. 87, No. 12, (December, 2000), pp. 1123-1132, ISSN 0009-7330

Gao, L.; Wang, W.; Li, Y.L.; Schultz, H.D.; Liu, D.; Cornish, K.G. \& Zucker, I.H. (2004). Superoxide mediates sympathoexcitation in heart failure: roles of angiotensin II and NAD(P)H oxidase. Circulation Research, Vol. 95, No. 9, (October, 2004), pp. 937944, ISSN 0009-7330

Gelband, C.H.; Warth, J.D.; Mason, H.S.; Zhu, M.; Moore, J.M.; Kenyon, J.L.; Horowitz, B. \& Sumners, C. (1999). Angiotensin II type 1 receptor-mediated inhibition of K+ channel subunit kv2.2 in brain stem and hypothalamic neurons. Circulation Research, Vol. 84, No. 3, (February, 1999), pp. 352-359, ISSN 0009-7330

Gill, G.V.; Woodward, A.; Casson, I.F. \& Weston, P.J. (2009). Cardiac arrhythmia and nocturnal hypoglycaemia in type 1 diabetes--the 'dead in bed' syndrome revisited. Diabetologia, Vol. 52, No. 1, (January, 2009), pp. 42-45, ISSN 0012-186X

Gouty, S.; Regalia, J. \& Helke, C.J. (2001). Attenuation of the afferent limb of the baroreceptor reflex in streptozotocin-induced diabetic rats. Autonomic Neuroscience, Vol. 89, No. 1-2, (June, 2001), pp. 86-95, ISSN 1566-0702

Griendling, K.K.; Sorescu, D. \& Ushio-Fukai, M. (2000). NAD(P)H oxidase: role in cardiovascular biology and disease. Circulation Research, Vol. 86, No. 5, (March, 2000), pp. 494-501, ISSN 0009-7330

Gu, H.; Epstein, P.N.; Li, L.; Wurster, R.D. \& Cheng, Z.J. (2008). Functional changes in baroreceptor afferent, central and efferent components of the baroreflex circuitry in type 1 diabetic mice (OVE26). Neuroscience, Vol. 152, No. 3, (March, 2008), pp. 741752, ISSN 0306-4522

Guven, A.; Yavuz, O.; Cam, M.; Comunoglu, C. \& Sevi'nc, O. (2009). Central nervous system complications of diabetes in streptozotocin-induced diabetic rats: a histopathological and immunohistochemical examination. International Journal of Neuroscience, Vol. 119, No.8, (August, 2009), pp. 1155-1169, ISSN 1563-5279

Hicks, K.K.; Seifen, E.; Stimers, J.R. \& Kennedy, R.H. (1998). Effects of streptozotocininduced diabetes on heart rate, blood pressure and cardiac autonomic nervous control. Journal of the Autonomic Nervous System, Vol. 69, No. 1, (March, 1998), pp. 21-30, ISSN 0165-1838

Horiuchi, M.; Akishita, M. \& Dzau, V.J. (1999). Recent progress in angiotensin II type 2 receptor research in the cardiovascular system. Hypertension, Vol. 33, No. 2, (February, 1999), pp. 613-621, ISSN 0194-911X 
Iovino, M.; Triggiani, V.; Licchelli, B.; Tafaro, E.; Giagulli, V.; Sabba, C.; Resta, F.; Sciannimanico, S.V.; Panza, R. \& Guastamacchia, E. (2011). Vasopressin release induced by hypotension is blunted in patients with diabetic autonomic neuropathy. Immunopharmacology and Immunotoxicology, Vol. 33, No. 1, (March, 2011), pp. 224226, ISSN 0892-3973

Ishii, T.M.; Takano, M.; Xie, L.H.; Noma, A. \& Ohmori, H. (1999). Molecular characterization of the hyperpolarization-activated cation channel in rabbit heart sinoatrial node. Journal of Biological Chemistry, Vol. 274, No. 18, (April, 1999), pp. 12835-12839, ISSN 0021-9258

Kamal, A.A.; Tay, S.S. \& Wong, W.C. (1991). The cardiac ganglia in streptozotocin-induced diabetic rats. Archives of Histology and Cytology, Vol. 54, No. 1, (March, 1991), pp. 4149, ISSN 0914-9465

Kang, J.; Richards, E.M.; Posner, P. \& Sumners, C. (1995). Modulation of the delayed rectifier $\mathrm{K}+$ current in neurons by an angiotensin II type 2 receptor fragment. American Journal of Physiology, Vol. 268, No. 1, (January, 1995), pp. C278-C282, ISSN 0002-9513

Karavanaki, K.; Kazianis, G.; Kakleas, K.; Konstantopoulos, I. \& Karayianni, C. (2007). QT interval prolongation in association with impaired circadian variation of blood pressure and heart rate in adolescents with Type 1 diabetes. Diabetic Medicine, Vol. 24, No. 11, (November, 2007), pp. 1247-1253, ISSN 0742-3071

Katz, A.; Liberty, I.F.; Porath, A.; Ovsyshcher, I. \& Prystowsky, E.N. (1999). A simple bedside test of 1-minute heart rate variability during deep breathing as a prognostic index after myocardial infarction. American Heart Journal, Vol. 138, No. 1, (July, 1999), pp. 32-38, ISSN 0002-8703

Kaupp, U.B. \& Seifert, R. (2001). Molecular diversity of pacemaker ion channels. Annual Review of Physiology, Vol. 63, pp. 235-257, ISSN 0066-4278

Kim, S. \& Iwao, H. (2000). Molecular and cellular mechanisms of angiotensin II-mediated cardiovascular and renal diseases. Pharmacological Reviews, Vol. 52, No. 1, (March, 2000), pp. 11-34, ISSN 0031-6997

Kim, Y.K.; Lee, J.E.; Kim, Y.G.; Kim, D.J.; Oh, H.Y.; Yang, C.W.; Kim, K.W. \& Huh, W. (2009). Cardiac autonomic neuropathy as a predictor of deterioration of the renal function in normoalbuminuric, normotensive patients with type 2 diabetes mellitus. Journal of Korean Medical Science, Vol. 24, No. suppl, (January, 2009), pp. S69-S74, ISSN 1011-8934

Kleiger, R.E.; Miller, J.P.; Bigger, J.T.Jr. \& Moss, A.J. (1987). Decreased heart rate variability and its association with increased mortality after acute myocardial infarction. American Journal of Cardiology, Vol. 59, No. 4, (February, 1987), pp. 256-262, ISSN 0002-9149

Kobayashi, M.; Cheng, Z.B.; Tanaka, K. \& Nosaka, S. (1999). Is the aortic depressor nerve involved in arterial chemoreflexes in rats? Journal of the Autonomic Nervous System, Vol. 78, No. 1, (October, 1999), pp. 38-48, ISSN 0165-1838

Kogawa, S.; Yasuda, H.; Terada, M.; Maeda, K. \& Kikkawa, R. (2000). Apoptosis and impaired axonal regeneration of sensory neurons after nerve crush in diabetic rats. Neuroreport, Vol. 11, No. 4, (March, 2000), pp. 663-667, ISSN 0959-4965

Krauhs, J.M. (1979). Structure of rat aortic baroreceptors and their relationship to connective tissue. Journal of Neurocytology, Vol. 8, No. 4, (August, 1979), pp. 401-414, ISSN 03004864 
Krolewski, A.S.; Kosinski, E.J.; Warram, J.H.; Leland, O.S.; Busick, E.J.; Asmal, A.C.; Rand, L.I.; Christlieb, A.R.; Bradley, R.F. \& Kahn, C.R. (1987). Magnitude and determinants of coronary artery disease in juvenile-onset, insulin-dependent diabetes mellitus. American Journal of Cardiology, Vol. 59, No. 8, (April, 1987), pp. 750-755, ISSN 0002-9149

Kuntscherova, J. \& Vlk, J. (1970). Influence of alloxan diabetes on acetylcholine synthesis in tissues of the albino rat. Physiologia Bohemoslovaca, Vol. 19, No. 5, pp. 431-434, ISSN 0369-9463

Lancaster, E.; Oh, E.J.; Gover, T. \& Weinreich, D. (2002). Calcium and calcium-activated currents in vagotomized rat primary vagal afferent neurons. Journal of Physiology, Vol. 540, No. 2, (April, 2002), pp. 543-556, ISSN 0022-3751

Lassegue, B. \& Clempus, R.E. (2003). Vascular NAD $(\mathrm{P}) \mathrm{H}$ oxidases: specific features, expression, and regulation. American Journal of Physiology Regulatory, Integrative and Comparative Physiology, Vol. 285, No. 2, (August, 2003), pp. R277-R297, ISSN 03636119

Lefrandt, J.D.; Hoogenberg, K.; van Roon, A.M.; Dullaart, R.P.; Gans, R.O. \& Smit, A.J. (1999). Baroreflex sensitivity is depressed in microalbuminuric Type I diabetic patients at rest and during sympathetic manoeuvres. Diabetologia, Vol. 42, No. 11, (November, 1999), pp. 1345-1349, ISSN 0012-186X

Lefrandt, J.D.; Smit, A.J.; Zeebregts, C.J.; Gans, R.O. \& Hoogenberg, K.H. (2010). Autonomic dysfunction in diabetes: a consequence of cardiovascular damage. Current Diabetes Reviews, Vol. 6, No. 6, (November, 2010), pp. 348-358, ISSN 1875-6417

Levy, B.I. (2004). Can angiotensin II type 2 receptors have deleterious effects in cardiovascular disease? Implications for therapeutic blockade of the reninangiotensin system. Circulation, Vol. 109, No. 1, (January, 2004), pp. 8-13, ISSN 0009-7322

Li, B.Y.; Alfrey, K.D. \& Schild, J.H. (2005). Correlation between the activation and inactivation gating profiles of the TTX-resistant $\mathrm{Na}^{+}$current from fluorescently identified aortic baroreceptor neurons of the adult rat. FASEB Journal, Vol. 19, No. 4, (March, 2005), pp. A606, ISSN 0892-6638

Li, B.Y. \& Schild, J.H. (2006). Differential distribution of voltage-gated $\mathrm{K}^{+}$ion channels in adult rat aortic baroreceptor neurons with myelinated and unmyelinated afferent fibre. FASEB Journal, Vol. 20, No. 4, (March, 2006), pp. A775, ISSN 0892-6638

Li, L.; Huang, C.; Ai, J.; Yan, B.; Gu, H.; Ma, Z.; Li, A.Y.; Xinyan, S.; Harden, S.W.; Hatcher, J.T.; Wurster, R.D. \& Cheng, Z.J. (2010). Structural remodeling of vagal afferent innervation of aortic arch and nucleus ambiguus (NA) projections to cardiac ganglia in a transgenic mouse model of type 1 diabetes (OVE26). Journal of Comparative Neurology, Vol. 518, No. 14, (July, 2010), pp. 2771-2793, ISSN 0021-9967

Li, Y.L.; Gao, L.; Zucker, I.H. \& Schultz, H.D. (2007). NADPH oxidase-derived superoxide anion mediates angiotensin II-enhanced carotid body chemoreceptor sensitivity in heart failure rabbits. Cardiovascular Research, Vol. 75, No. 3, (August, 2007), pp. 546554, ISSN 0008-6363

Li, Y.L.; Tran, T.P.; Muelleman, R. \& Schultz, H.D. (2008a). Blunted excitability of aortic baroreceptor neurons in diabetic rats: involvement of hyperpolarization-activated channel. Cardiovascular Research, Vol. 79, No. 4, (September, 2008), pp. 715-721, ISSN 0008-6363 
Li, Y.L.; Tran, T.P.; Muelleman, R. \& Schultz, H.D. (2008b). Elevated angiotensin II in rat nodose ganglia mediates diabetes-blunted arterial baroreflex sensitivity. Circulation, Vol. 118, No. 18, (Vovember, 2008), pp. S360, ISSN 0009-7322

Li, Y.L. \& Zheng, H. (2011). Angiotensin II-NADPH oxidase-derived superoxide mediates diabetes-attenuated cell excitability of aortic baroreceptor neurons. Cardiovascular Research, In press, ISSN 0008-6363

Libby, P.; Nathan, D.M.; Abraham, K.; Brunzell, J.D.; Fradkin, J.E.; Haffner, S.M.; Hsueh, W.; Rewers, M.; Roberts, B.T.; Savage, P.J.; Skarlatos, S.; Wassef, M. \& Rabadan-Diehl, C. (2005). Report of the National Heart, Lung, and Blood Institute-National Institute of Diabetes and Digestive and Kidney Diseases Working Group on Cardiovascular Complications of Type 1 Diabetes Mellitus. Circulation, Vol. 111, No. 25, (June, 2005), pp. 3489-3493, ISSN 0009-7322

Lin, M.; Ai, J.; Harden, S.W.; Huang, C.; Li, L.; Wurster, R.D. \& Cheng, Z.J. (2010). Impairment of baroreflex control of heart rate and structural changes of cardiac ganglia in conscious streptozotocin (STZ)-induced diabetic mice. Autonomic Neuroscience, Vol. 155, No. 1-2, (June, 2010), pp. 39-48, ISSN 1566-0702

Lishner, M.; Akselrod, S.; Avi, V.M.; Oz, O.; Divon, M. \& Ravid, M. (1987). Spectral analysis of heart rate fluctuations. A non-invasive, sensitive method for the early diagnosis of autonomic neuropathy in diabetes mellitus. Journal of the Autonomic Nervous System, Vol. 19, No. 2, (May, 1987), pp. 119-125, ISSN 0165-1838

Lluch, I.; Hernandez, A.; Real, J.T.; Morillas, C.; Tenes, S.; Sanchez, C. \& Ascaso, J.F. (1998). Cardiovascular autonomic neuropathy in type 1 diabetic patients with and without peripheral neuropathy. Diabetes Research and Clinical Practice, Vol. 42, No. 1, (October, 1998), pp. 35-40, ISSN 0168-8227

Low, P.A.; Walsh, J.C.; Huang, C.Y. \& McLeod, J.G. (1975). The sympathetic nervous system in alcoholic neuropathy. A clinical and pathological study. Brain, Vol. 98, No. 3, (September, 1975), pp. 357-364, ISSN 0006-8950

Ludwig, A.; Zong, X.; Jeglitsch, M.; Hofmann, F. \& Biel, M. (1998). A family of hyperpolarization-activated mammalian cation channels. Nature, Vol. 393, No. 6685, (June, 1998), pp. 587-591, ISSN 0028-0836

Ludwig, A.; Zong, X.; Stieber, J.; Hullin, R.; Hofmann, F. \& Biel, M. (1999). Two pacemaker channels from human heart with profoundly different activation kinetics. EMBO Journal, Vol. 18, No. 9, (May, 1999), pp. 2323-2329, ISSN 0261-4189

Lund, D.D.; Subieta, A.R.; Pardini, B.J. \& Chang, K.S. (1992). Alterations in cardiac parasympathetic indices in STZ-induced diabetic rats. Diabetes, Vol. 41, No. 2, (February, 1992), pp. 160-166, ISSN 0012-1797

Maeda, C.Y.; Fernandes, T.G.; Timm, H.B. \& Irigoyen, M.C. (1995). Autonomic dysfunction in short-term experimental diabetes. Hypertension, Vol. 26, No. 6, (December, 1995), pp. 1100-1104, ISSN 0194-911X

Maliszewska-Scislo, M.; Scislo, T.J. \& Rossi, N.F. (2003). Effect of blockade of endogenous angiotensin II on baroreflex function in conscious diabetic rats. American Journal of Physiology Heart and Circulatory Physiology, Vol. 284, No. 5, (May, 2003), pp. H1601H1611, ISSN 0363-6135

Martens, J.R.; Wang, D.; Sumners, C.; Posner, P. \& Gelband, C.H. (1996). Angiotensin II type 2 receptor-mediated regulation of rat neuronal $\mathrm{K}^{+}$channels. Circulation Research, Vol. 79, No. 2, (August, 1996), pp. 302-309, ISSN 0009-7330 
Maser, R.E.; Mitchell, B.D.; Vinik, A.I. \& Freeman, R. (2003). The association between cardiovascular autonomic neuropathy and mortality in individuals with diabetes: a meta-analysis. Diabetes Care, Vol. 26, No. 6, (June, 2003), pp. 1895-1901, ISSN 01495992

Matsubara, H. (1998). Pathophysiological role of angiotensin II type 2 receptor in cardiovascular and renal diseases. Circulation Research, Vol. 83, No. 12, (December, 1998), pp. 1182-1191, ISSN 0009-7330

McDowell, T.S.; Chapleau, M.W.; Hajduczok, G. \& Abboud, F.M. (1994a). Baroreflex dysfunction in diabetes mellitus. I. Selective impairment of parasympathetic control of heart rate. American Journal of Physiology, Vol. 266, No. 1, (January, 1994), pp. H235-H243, ISSN 0002-9513

McDowell, T.S.; Hajduczok, G.; Abboud, F.M. \& Chapleau, M.W. (1994b). Baroreflex dysfunction in diabetes mellitus. II. Site of baroreflex impairment in diabetic rabbits. American Journal of Physiology, Vol. 266, No. 1, (January, 1994), pp. H244H249, ISSN 0002-9513

Messent, J.W.; Elliott, T.G.; Hill, R.D.; Jarrett, R.J.; Keen, H. \& Viberti, G.C. (1992). Prognostic significance of microalbuminuria in insulin-dependent diabetes mellitus: a twentythree year follow-up study. Kidney International, Vol. 41, No. 4, (April, 1992), pp. 836-839, ISSN 0085-2538

Minokoshi, Y.; Haque, M.S. \& Shimazu, T. (1999). Microinjection of leptin into the ventromedial hypothalamus increases glucose uptake in peripheral tissues in rats. Diabetes, Vol. 48, No. 2, (February, 1999), pp. 287-291, ISSN 0012-1797

Mooradian, A.D. (1997a). Central nervous system complications of diabetes mellitus--a perspective from the blood-brain barrier. Brain Research Reviews, Vol. 23, No. 3, (April, 1997), pp. 210-218, ISSN 0165-0173

Mooradian, A.D. (1997b). Pathophysiology of central nervous system complications in diabetes mellitus. Clinical Neuroscience, Vol. 4, No. 6, pp. 322-326, ISSN 1065-6766

Moosmang, S.; Stieber, J.; Zong, X.; Biel, M.; Hofmann, F. \& Ludwig, A. (2001). Cellular expression and functional characterization of four hyperpolarization-activated pacemaker channels in cardiac and neuronal tissues. European Journal of Biochemistry, Vol. 268, No. 6, (March, 2001), pp. 1646-1652, ISSN 0014-2956

Moreira, T.H.; Rodrigues, A.L.; Beirao, P.S.; dos Santos, R.A. \& Santos, C.J. (2005). Angiotensin II inhibition of Ca2+ currents is independent of ATR1 angiotensin II receptor activation in rat adult vagal afferent neurons. Autonomic Neuroscience, Vol. 117, No. 2, (February, 2005), pp. 79-86, ISSN 1566-0702

Notomi, T. \& Shigemoto, R. (2004). Immunohistochemical localization of th channel subunits, HCN1-4, in the rat brain. Journal of Comparative Neurology, Vol. 471, No. 3, (April, 2004), pp. 241-276, ISSN 0021-9967

O'Brien, I.A.; McFadden, J.P. \& Corrall, R.J. (1991). The influence of autonomic neuropathy on mortality in insulin-dependent diabetes. Quarterly Journal of Medicine, Vol. 79, No. 290, (June, 1991), pp. 495-502, ISSN 0033-5622

Orchard, T.J.; Lloyd, C.E.; Maser, R.E. \& Kuller, L.H. (1996). Why does diabetic autonomic neuropathy predict IDDM mortality? An analysis from the Pittsburgh Epidemiology of Diabetes Complications Study. Diabetes Research and Clinical Practice, Vol. 34, No. suppl, (October, 1996), pp. S165-S171, ISSN 0168-8227 
Page, M.M. \& Watkins, P.J. (1978). Cardiorespiratory arrest and diabetic autonomic neuropathy. Lancet, Vol. 1, No. 8054, (January, 1978), pp. 14-16, ISSN 0140-6736

Pape, H.C. (1996). Queer current and pacemaker: the hyperpolarization-activated cation current in neurons. Annual Review of Physiology, Vol. 58, pp. 299-327, ISSN 00664278

Pavy-Le, T.A.; Fontaine, S.; Tap, G.; Guidolin, B.; Senard, J.M. \& Hanaire, H. (2010). Cardiovascular autonomic neuropathy and other complications in type 1 diabetes. Clinical Autonomic Research, Vol. 20, No. 3, (June, 2010), pp. 153-160, ISSN 0959-9851

Qu, J.; Altomare, C.; Bucchi, A.; DiFrancesco, D. \& Robinson, R.B. (2002). Functional comparison of HCN isoforms expressed in ventricular and HEK 293 cells. Pflugers Archive, Vol. 444, No. 5, (August, 2002), pp. 597-601, ISSN 0031-6768

Rathmann, W.; Ziegler, D.; Jahnke, M.; Haastert, B. \& Gries, F.A. (1993). Mortality in diabetic patients with cardiovascular autonomic neuropathy. Diabetic Medicine, Vol. 10, No. 9, (November, 1993), pp. 820-824, ISSN 0742-3071

Reynolds, P.J.; Fan, W. \& Andresen, M.C. (1999). Aortic baroreceptor function in long term streptozotocin diabetic rats. Social Neuroscience, Vol. 16, pp. 221, ISSN 1747-0919

Reynolds, P.J.; Yang, M. \& Andresen, M.C. (1994). Contribution of potassium channels to the discharge properties of rat aortic baroreceptor sensory endings. Brain Research, Vol. 665, No. 1, (November, 1994), pp. 115-122, ISSN 0006-8993

Robinson, R.B. \& Siegelbaum, S.A. (2003). Hyperpolarization-activated cation currents: from molecules to physiological function. Annual Review of Physiology, Vol. 65, pp. 453480, ISSN 0066-4278

Rosengard-Barlund, M.; Bernardi, L.; Fagerudd, J.; Mantysaari, M.; Af Bjorkesten, C.G.; Lindholm, H.; Forsblom, C.; Waden, J. \& Groop, P.H. (2009). Early autonomic dysfunction in type 1 diabetes: a reversible disorder? Diabetologia, Vol. 52, No. , (June, 2009), pp. 1164-1172, ISSN 0012-186X

Russell, J.W.; Sullivan, K.A.; Windebank, A.J.; Herrmann, D.N. \& Feldman, E.L. (1999). Neurons undergo apoptosis in animal and cell culture models of diabetes. Neurobiology of Disease, Vol. 6, No. 5, (October, 1999), pp. 347-363, ISSN 0969-9961

Salgado, H.C.; Barale, A.R.; Castania, J.A.; Machado, B.H. Chapleau, M.W. \& Fazan, R.Jr. (2007). Baroreflex responses to electrical stimulation of aortic depressor nerve in conscious SHR. American Journal of Physiology Heart and Circulatory Physiology, Vol. 292, No. 1, (January, 2007), pp. H593-H600, ISSN 0363-6135

Salgado, H.C.; Fazan, J.R.; Fazan, V.P. Da, S.V, \& Barreira, A.A. (2001). Arterial baroreceptors and experimental diabetes. Annals of the New York Academy of Sciences, Vol. 940, (June, 2001), pp. 20-27, ISSN 0077-8923

Sango, K.; Horie, H. \& Inoue, S. (1997). Biophysical and biochemical features of diabetic neurons in culture: what have we learned about diabetic neuropathy? Journal of the Peripheral Nervous System, Vol. 2, No. 3, pp. 203-211, ISSN 1085-9489

Sango, K.; Horie, H.; Okamura, A.; Inoue, S. \& Takenaka, T. (1995). Diabetes impairs DRG neuronal attachment to extracellular matrix proteins in vitro. Brain Research Bulletin, Vol. 37, No. 5, pp. 533-537, ISSN 0361-9230

Sango, K.; Horie, H.; Saito, H.; Ajiki, K.; Tokashiki, A.; Takeshita, K.; Ishigatsubo, Y.; Kawano, H. \& Ishikawa, Y. (2002). Diabetes is not a potent inducer of neuronal cell death in mouse sensory ganglia, but it enhances neurite regeneration in vitro. Life Sciences, Vol. 71, No. 20, (October, 2002), pp. 2351-2368, ISSN 0024-3205 
Sango, K.; Horie, H.; Sotelo, J.R. \& Takenaka, T. (1991). A high glucose environment improves survival of diabetic neurons in culture. Neuroscience Letters, Vol. 129, No. 2, (August, 1991), pp. 277-280, ISSN 0304-3940

Santoro, B.; Liu, D.T.; Yao, H.; Bartsch, D.; Kandel, E.R.; Siegelbaum, S.A. \& Tibbs, G.R. (1998). Identification of a gene encoding a hyperpolarization-activated pacemaker channel of brain. Cell, Vol. 93, No. 5, (May, 1998), pp. 717-729, ISSN 0092-8674

Sapru, H.N.; Gonzalez, E. \& Krieger, A.J. (1981). Aortic nerve stimulation in the rat: cardiovascular and respiratory responses. Brain Research Bulletin, Vol. 6, No. 5, (May, 1981), pp. 393-398, ISSN 0361-9230

Sapru, H.N. \& Krieger, A.J. (1977). Carotid and aortic chemoreceptor function in the rat. Journal of Applied Physiology, Vol. 42, No. 3, (March, 1977), pp. 344-348, ISSN 87507587

Schieffer, B.; Luchtefeld, M.; Braun, S.; Hilfiker, A.; Hilfiker-Kleiner, D. \& Drexler, H. (2000). Role of $\mathrm{NAD}(\mathrm{P}) \mathrm{H}$ oxidase in angiotensin II-induced JAK/STAT signaling and cytokine induction. Circulation Research, Vol. 87, No. 12, (December, 2000), pp. 11951201, ISSN 0009-7330

Schild, J.H. \& Li, B.Y. (2001). The N-type Ca ${ }^{2+}$ current is not responsible for the repolarization 'hump' in the action potential of nodose sensory neurons. FASEB Journal, Vol. 15, No. 5, (March, 2001), pp. A1150, ISSN 0892-6638

Seagard, J.L.; Hopp, F.A.; Drummond, H.A. \& Van Wynsberghe, D.M. (1993). Selective contribution of two types of carotid sinus baroreceptors to the control of blood pressure. Circulation Research, Vol. 72, No. 5, (May, 1993), pp. 1011-1022, ISSN 00097330

Sechi, L.A.; Griffin, C.A. \& Schambelan, M. (1994). The cardiac renin-angiotensin system in STZ-induced diabetes. Diabetes, Vol. 43, No. 10, (October, 1994), pp. 1180-1184, ISSN 0012-1797

Selvarajah, D. \& Tesfaye, S. (2006). Central nervous system involvement in diabetes mellitus. Current Diabetes Report, Vol. 6, No. 6, (December, 2006), pp. 431-438, ISSN 1534-4827

Sharma, A.K. \& Thomas, P.K. (1987). Animal models: pathophysiology, In: Diabetic Neuropathy, Dyck, P.J.; Thomas, P.K.; Asbury, A.K.; Winegrad, A.I. \& Porte, D. (Eds.), pp. 237-252. ISBN 0721621252, Saunders, Philadelphia

Shimoni, Y. \& Liu, X.F. (2004). Gender differences in ANG II levels and action on multiple $\mathrm{K}+$ current modulation pathways in diabetic rats. American Journal of Physiology Heart and Circulatory Physiology, Vol. 287, No. 1, (July, 2004), pp. H311-H319, ISSN 0363-6135

Siragy, H.M. (2000). The role of the AT2 receptor in hypertension. American Journal of Hypertension, Vol. 13, No. 5, (May, 2000), pp. 62S-67S, ISSN 0895-7061

Soedamah-Muthu, S.S.; Chaturvedi, N.; Witte, D.R.; Stevens, L.K.; Porta, M. \& Fuller, J.H. (2008). Relationship between risk factors and mortality in type 1 diabetic patients in Europe: the EURODIAB Prospective Complications Study (PCS). Diabetes Care, Vol. 31, No. 7, (August, 2008), pp. 1360-1366, ISSN 0149-5992

Spyer, K.M.; Lambert, J.H. \& Thomas, T. (1997). Central nervous system control of cardiovascular function: neural mechanisms and novel modulators. Clinical and Experimental Pharmacology and Physiology, Vol. 24, No. 9-10, (September, 1997), pp. 743-747, ISSN 0305-1870 
Srinivasan, S.; Stevens, M. \& Wiley, J.W. (2000). Diabetic peripheral neuropathy: evidence for apoptosis and associated mitochondrial dysfunction. Diabetes, Vol. 49, No. 11, (November, 2000), pp. 1932-1938, ISSN 0012-1797

Stieber, J.; Stockl, G.; Herrmann, S.; Hassfurth, B. \& Hofmann, F. (2005). Functional expression of the human HCN3 channel. Journal of Biological Chemistry, Vol. 280, No. 41, (October, 2005), pp. 34635-34643, ISSN 0021-9258

Stieber, J.; Thomer, A.; Much, B.; Schneider, A.; Biel, M. \& Hofmann, F. (2003). Molecular basis for the different activation kinetics of the pacemaker channels HCN2 and HCN4. Journal of Biological Chemistry, Vol. 278, No. 36, (September, 2003), pp. 3367233680, ISSN 0021-9258

Sumners, C.; Zhu, M.; Gelband, C.H. \& Posner, P. (1996). Angiotensin II type 1 receptor modulation of neuronal $\mathrm{K}^{+}$and $\mathrm{Ca}^{2+}$ currents: intracellular mechanisms. American Journal of Physiology, Vol. 271, No. 1, (July, 1996), pp. C154-C163, ISSN 0002-9513

Tang, X. \& Dworkin, B.R. (2007). Baroreflexes of the rat. V. Tetanus-induced potentiation of ADN A-fiber responses at the NTS. American Journal of Physiology Regulatory, Integrative and Comparative Physiology, Vol. 293, No. 6, (December, 2007), pp. R2254R2259, ISSN 0363-6119

Tattersall, R.B. \& Gill, G.V. (1991). Unexplained deaths of type 1 diabetic patients. Diabetic Medicine, Vol. 8, No. 1, (January, 1991), pp. 49-58, ISSN 0742-3071

Thomas, P.K. \& Tomlinson, D.R. (1993). Diabetic and hypoglycemic neuropathy, In: Peripheral neuropathy, Dyck, P.J. \& Thomas, P.K. (Eds.), pp. 1219-1250, ISBN 0721644317, Saunders, Philadelphia

Thoren, P.; Munch, P.A. \& Brown, A.M. (1999). Mechanisms for activation of aortic baroreceptor C-fibres in rabbits and rats. Acta Physiologica Scandinavica, Vol. 166, No. 3, (July, 1999), pp. 167-174, ISSN 0001-6772

Touyz, R.M. \& Berry, C. (2002). Recent advances in angiotensin II signaling. Brazilizan Journal of Medical Biological Research, Vol. 35, No. 9, (September, 2002), pp. 10011015, ISSN 0100-879X

Toyry, J.P.; Partanen, J.V.; Niskanen, L.K.; Lansimies, E.A. \& Uusitupa, M.I. (1997). Divergent development of autonomic and peripheral somatic neuropathies in NIDDM. Diabetologia, Vol. 40, No. 8, (August, 1997), pp. 953-958, ISSN 0012-186X

Tsujimura, T.; Nunotani, H.; Fushimi, H. \& Inoue, T. (1986). Morphological changes in autonomic ganglionic cells of the heart in diabetic patients. Diabetes Research and Clinical Practice, Vol. 2, No. 3, (June, 1986), pp. 133-137, ISSN 0168-8227

Tu, H.; Zhang, L.; Tran, T.P.; Muelleman, R.L. \& Li, Y.L. (2010). Diabetes alters protein expression of hyperpolarization-activated cyclic nucleotide-gated channel subunits in rat nodose ganglion cells. Neuroscience, Vol. 165, No. 1, (January, 2010), pp. 39-52, ISSN 0306-4522

Vaccari, T.; Moroni, A.; Rocchi, M.; Gorza, L.; Bianchi, M.E.; Beltrame, M. \& DiFrancesco, D, (1999). The human gene coding for HCN2, a pacemaker channel of the heart. Biochimica et Biophysicac Acta, Vol. 1446, No. 3, (September, 1999), pp. 419-425, ISSN 0006-3002

Valensi, P.; Sachs, R.N.; Harfouche, B.; Lormeau, B.; Paries, J.; Cosson, E.; Paycha, F.; Leutenegger, M. \& Attali, J.R. (2001). Predictive value of cardiac autonomic neuropathy in diabetic patients with or without silent myocardial ischemia. Diabetes Care, Vol. 24, No. 2, (February, 2001), pp. 339-343, ISSN 0149-5992 
Van, B.T.; Kasbergen, C.M.; Gispen, W.H. \& De Wildt, D.J. (1998). In vivo cardiovascular reactivity and baroreflex activity in diabetic rats. Cardiovascular Research, Vol. 38, No. 3, (June, 1998), pp. 763-771, ISSN 0008-6363

Vinik, A.I. \& Ziegler, D. (2007). Diabetic cardiovascular autonomic neuropathy. Circulation, Vol. 115, No. 3, (January, 2007), pp. 387-397, ISSN 0009-7322

Wahl-Schott, C. \& Biel, M. (2009). HCN channels: structure, cellular regulation and physiological function. Cellular and Molecular Life Sciences, Vol. 66, No. 3, (February, 2009), pp. 470-494, ISSN 1420-682X

Wainger, B.J.; DeGennaro, M.; Santoro, B.; Siegelbaum, S.A. \& Tibbs, G.R. (2001). Molecular mechanism of cAMP modulation of HCN pacemaker channels. Nature, Vol. 411, No. 6839, (June, 2001), pp. 805-810, ISSN 0028-0836

Wang, J.; Chen, S.; Nolan, M.F. \& Siegelbaum, S.A. (2002). Activity-dependent regulation of HCN pacemaker channels by cyclic AMP: signaling through dynamic allosteric coupling. Neuron, Vol. 36, No. 3, (October, 2002), pp. 451-461, ISSN 0896-6273

Wang, J.; Chen, S.; \& Siegelbaum, S.A. (2001). Regulation of hyperpolarization-activated $\mathrm{HCN}$ channel gating and cAMP modulation due to interactions of $\mathrm{COOH}$ terminus and core transmembrane regions. Journal of General Physiology, Vol. 118, No. 3, (September, 2001), pp. 237-250, ISSN 0022-1295

Wang, J.L.; Chinookoswong, N.; Scully, S.; Qi, M. \& Shi, Z.Q. (1999). Differential effects of leptin in regulation of tissue glucose utilization in vivo. Endocrinology, Vol. 140, No. 5, (May, 1999), pp. 2117-2124, ISSN 0013-7227

Weinrauch, L.A.; Kennedym, F.P.; Gleason, R.E.; Keough, J. \& D'Elia, J.A. (1998). Relationship between autonomic function and progression of renal disease in diabetic proteinuria: clinical correlations and implications for blood pressure control. American Journal of Hypertension, Vol. 11, No. 3, (March, 1998), pp. 302-308, ISSN 0895-7061

Weston, P.J. \& Gill, G.V. (1999). Is undetected autonomic dysfunction responsible for sudden death in Type 1 diabetes mellitus? The 'dead in bed' syndrome revisited. Diabetic Medicine, Vol. 16, No. 8, (August, 1999), pp. 626-631, ISSN 0742-3071

Weston, P.J.; James, M.A.; Panerai, R.; McNally, P.G.; Potter, J.F.; Thurston, H. \& Swales, J.D. (1996). Abnormal baroreceptor-cardiac reflex sensitivity is not detected by conventional tests of autonomic function in patients with insulin-dependent diabetes mellitus. Clinical Science (London), Vol. 91, No. 1, (July, 1996), pp. 59-64, ISSN 0143-5221

Weston, P.J.; James, M.A.; Panerai, R.B.; McNally, P.G.; Potter, J.F. \& Thurston, H. (1998). Evidence of defective cardiovascular regulation in insulin-dependent diabetic patients without clinical autonomic dysfunction. Diabetes Research and Clinical Practice, Vol. 42, No. 3, (December, 1998), pp. 141-148, ISSN 0168-8227

Widdop, R.E.; Krstew, E. \& Jarrott, B. (1992). Electrophysiological responses of angiotensin peptides on the rat isolated nodose ganglion. Clinical $\mathcal{E}$ Experimental Hypertension. Part A, Vol. 14, No. 4, pp. 597-613, ISSN 1064-1963

Xiao, L.; Wu, Y.M.; Wang, R.; Liu, Y.X.; Wang, F.W. \& He, R.R. (2007). Hydrogen sulfide facilitates carotid sinus baroreceptor activity in anesthetized male rats. Chinese Medical Journal (English) , Vol. 120, No. 15, (August, 2007), pp. 1343-1347, ISSN 0336-6999 
Yagihashi, S. (1995). Pathology and pathogenetic mechanisms of diabetic neuropathy. Diabetes/Metabolism Reviews, Vol. 11, No. 3, (October, 1995), pp. 193-225, ISSN 07424221

Yagihashi, S. (1997). Pathogenetic mechanisms of diabetic neuropathy: lessons from animal models. Journal of the Peripheral Nervous System, Vol. 2, No. 2, (June, 1997), pp. 113132, ISSN 1085-9489

Yamasaki, M.; Shimizu, T.; Katahira, K.; Waki, H.; Nagayama, T.; Ishi, H.; Katsuda, S.; Miyake, M.; Miyamoto, Y.; Wago, H.; Okouchi, T. \& Matsumoto, S. (2004). Spaceflight alters the fiber composition of the aortic nerve in the developing rat. Neuroscience, Vol. 128, No. 4, pp. 819-829, ISSN 0306-4522

Zhang, H.; Liu, Y.X.; Wu, Y.M.; Wang, Z.M. \& He, R.R. (2004). Capsaicin facilitates carotid sinus baroreceptor activity in anesthetized rats. Acta Pharmacologica Sinica, Vol. 25, No. 11, (November, 2004), pp. 1439-1443, ISSN 1671-4083

Zhang, L.; Tu, H. \& Li, Y.L. (2010). Angiotensin II enhances hyperpolarization-activated currents in rat aortic baroreceptor neurons: involvement of superoxide. American Journal of Physiology Cell Physiology, Vol. 298, No. 1, (January, 2010), pp. C98-C106, ISSN 0363-6143

Zhuo, J.L.; Imig, J.D.; Hammond, T.G.; Orengo, S.; Benes, E. \& Navar, L.G. (2002). Ang II accumulation in rat renal endosomes during Ang II-induced hypertension: role of AT(1) receptor. Hypertension, Vol. 39, No. 1, (January, 2002), pp. 116-121, ISSN 0194$911 \mathrm{X}$

Ziegler, D. (1994). Diabetic cardiovascular autonomic neuropathy: prognosis, diagnosis and treatment. Diabetes/Metabolism Reviews, Vol. 10, No. 4, (December, 1994), pp. 339383, ISSN 0742-4221

Ziegler D, Laude D, Akila F, \& Elghozi JL (2001). Time- and frequency-domain estimation of early diabetic cardiovascular autonomic neuropathy. Clinical Autonomic Research, Vol. 11, No. 6, (December, 2001), pp. 369-376, ISSN 0959-9851 


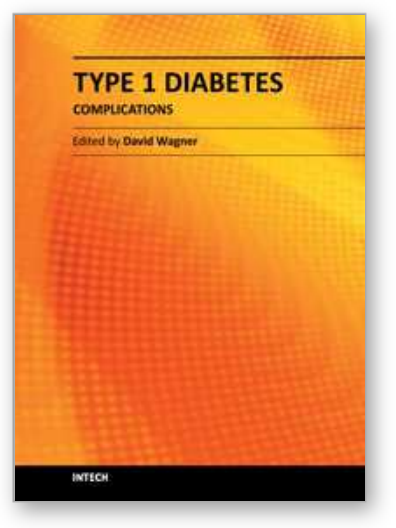

\author{
Type 1 Diabetes Complications \\ Edited by Prof. David Wagner
}

ISBN 978-953-307-788-8

Hard cover, 482 pages

Publisher InTech

Published online 25, November, 2011

Published in print edition November, 2011

This book is a compilation of reviews about the complication of Type 1 Diabetes. T1D is a classic autoimmune disease. Genetic factors are clearly determinant but cannot explain the rapid, even overwhelming expanse of this disease. Understanding etiology and pathogenesis of this disease is essential. The complications associated with T1D cover a range of clinical obstacles. A number of experts in the field have covered a range of topics for consideration that are applicable to researcher and clinician alike. This book provides apt descriptions of cutting edge technologies and applications in the ever going search for treatments and cure for diabetes.

\title{
How to reference
}

In order to correctly reference this scholarly work, feel free to copy and paste the following:

Yu-Long Li (2011). Cardiovascular Autonomic Dysfunction in Diabetes as a Complication: Cellular and Molecular Mechanisms, Type 1 Diabetes Complications, Prof. David Wagner (Ed.), ISBN: 978-953-307-788-8, InTech, Available from: http://www.intechopen.com/books/type-1-diabetes-complications/cardiovascularautonomic-dysfunction-in-diabetes-as-a-complication-cellular-and-molecular-mechanisms

\section{INTECH}

open science | open minds

\section{InTech Europe}

University Campus STeP Ri

Slavka Krautzeka 83/A

51000 Rijeka, Croatia

Phone: +385 (51) 770447

Fax: +385 (51) 686166

www.intechopen.com

\section{InTech China}

Unit 405, Office Block, Hotel Equatorial Shanghai

No.65, Yan An Road (West), Shanghai, 200040, China

中国上海市延安西路65号上海国际贵都大饭店办公楼 405 单元

Phone: +86-21-62489820

Fax: $+86-21-62489821$ 
(C) 2011 The Author(s). Licensee IntechOpen. This is an open access article distributed under the terms of the Creative Commons Attribution 3.0 License, which permits unrestricted use, distribution, and reproduction in any medium, provided the original work is properly cited. 